\title{
IDENTIFYING AND PRIORITIZING COST REDUCTION SOLUTIONS IN THE SUPPLY CHAIN BY INTEGRATING VALUE ENGINEERING AND GRAY MULTI-CRITERIA DECISION-MAKING
}

\author{
Jalil HEIDARY DAHOOIE (D) ${ }^{*}$, Seyyed Jalaladdin HOSSEINI DEHSHIRI ${ }^{(12}{ }^{2}$ \\ Audrius BANAITIS (D) ${ }^{3 *}$, Arūnè BINKYTÉ-VÉLIENE் (iD 4 \\ ${ }^{1}$ Department of Industrial Management, Faculty of Management, University of Tehran, Tehran, Iran \\ ${ }^{2}$ Department of Industrial Management, Faculty of Management and Accounting, \\ Allameh Tabataba'i University, Tehran, Iran \\ ${ }^{3}$ Department of Construction Management and Real Estate, Faculty of Civil Engineering, \\ Vilnius Gediminas Technical University, Vilnius, Lithuania \\ ${ }^{4}$ Laboratory of Smart Building Systems, Institute of Sustainable Construction, \\ Faculty of Civil Engineering, Vilnius Gediminas Technical University, Vilnius, Lithuania
}

Received 28 March 2020; accepted 12 July 2020

\begin{abstract}
Value engineering is an appropriate policy for creating and improving value, which reduces unnecessary costs and maintains core functionality. Despite the mentioned benefits, this approach has so far received little attention in the area of supply chain management. Although this approach is highly structured, limitations such as overemphasizing the cost criterion and failure to meet other criteria, utilizing team members' votes to rank solutions, ignoring inherent uncertainty and ultimately disagreement between value engineering team members have reduced the effectiveness of this approach. The present study aims to provide a coherent framework for utilizing a value engineering approach to supply chain cost management and overcome the aforementioned limitations by utilizing gray multi-criteria decision-making. In this regard, in the first phase, the initial list of improvement solutions is determined, the criteria extracted from the literature are localized using value engineering team members' opinion. These criteria are weighted using the gray stepwise weight assessment ratio analysis (SWARA-Gray) method. Then, the score of each solution is calculated by the value engineering team based on the list of criteria as a gray number. The scores are aggregated using the gray evaluation based on distance from average solution (EDAS-Gray) method, and the solutions are prioritized. Finally, the application of the proposed framework is investigated in a real case study in a power plant in Iran. The results of the research show that the final rankings of the solutions rarely changed for different methods; so the model used in this study has acceptable stability.
\end{abstract}

Keywords: value engineering, SWARA-Gray, EDAS-Gray, supply chain, cost reduction solutions.

JEL Classification: C02, C44, D24, D70, L60.

*Corresponding author. E-mail: heidaryd@ut.ac.ir

\#Corresponding author. E-mail: audrius.banaitis@vgtu.lt

Copyright (c) 2020 The Author(s). Published by Vilnius Gediminas Technical University

This is an Open Access article distributed under the terms of the Creative Commons Attribution License (http://creativecommons. org/licenses/by/4.0/), which permits unrestricted use, distribution, and reproduction in any medium, provided the original author and source are credited. 


\section{Introduction}

In today's competitive environment, companies no longer compete individually but as supply chains (Carvalho \& Cruz-Machado, 2011; Amiri et al., 2020). The supply chain is defined as a network of different entities that connects the customer to the supplier through production and service delivery so that materials, money, and information flow effectively to meet business needs (Azevedo et al., 2011; Elgazzar et al., 2012; Chopra \& Meindl, 2013). The rise of sustainable supply chain management, have made global operations more manageable and lead to economic development (Carter \& Rogers, 2008; Buckley, 2009; Kumar et al., 2020a). Supply chain management is considered as a business strategy for enhancing organizational effectiveness and achieving organizational goals including increased competitive advantage, better customer service, and increased profitability (Gunasekaran et al., 2001). In recent years, lean, agile, resilient, and green paradigms have been introduced to increase supply chain efficiency, effectiveness, and sustainability (Maleki \& Machado, 2013; Azevedo et al., 2011; Kumar et al., 2019, 2020b). The need to pay attention to the concept of competition and performance improvement at the supply chain level has led to theoretical and executive efforts to integrate traditional paradigms (Carvalho et al., 2011). In this regard, new integrated paradigms such as lean and agile (Fan et al., 2007), lean and green (Al-Aomar \& Weriakat, 2012), lean, green, and resilience (Govindan et al., 2015), lean, agile, resilience, and green (Carvalho \& Azevedo, 2014; Carvalho et al., 2011; Bai \& Sarkis, 2018; Chatterjee et al., 2018), etc. were formed. By examining the formation process of these paradigms, it can be asserted that the lean paradigm has always been one of the key components of integrated supply chain performance improvement paradigms (Jasti \& Kodali, 2015; Manzouri \& Ab Rahman, 2013; Nascimento et al., 2018).

A lean paradigm is a systematic approach to identify and eliminate non-value-adding activities through continuous improvement to meet customer needs and maintain benefits (Azevedo et al., 2010; Behncke et al., 2014). Numerous definitions of the lean paradigm have been identified in the literature, all of which are based on the principle of minimizing cost and eliminating wastes (Cabral et al., 2012) by focusing on process improvement to reduce unnecessary activities, and increase time, manpower, equipment, space, and resources across the supply chain (Browning, 2000; Corbett \& Klassen, 2006; Carvalho et al., 2010). Since the primary goal in the lean paradigm is to minimize cost and eliminate wastes (Cabral et al., 2012), reducing supply chain costs as a tool for achieving competitive advantage has always been emphasized by researchers in this field ( $\mathrm{Su} \&$ Lei, 2008). Proper utilization of supply chain cost reduction solutions helps organizations respond effectively to changing market/ customer needs while maintaining flexibility (Gunasekaran et al., 2008).

On the other hand, with the emergence of global and highly competitive markets, providing valuable products to customers at the lowest price and cost becomes one of the most important factors in the success of the competition (Tohidi, 2011). So, organizations have placed both performance and cost metrics at the heart of their plans for achieving a competitive advantage (Ibusuki \& Kaminski, 2007). Accordingly, various techniques have been proposed for cost management, and undoubtedly value engineering is one of the most effective techniques (Annappa \& Panditrao, 2012) that was introduced in 1940 by Lawrence Miles (Shen \& Yu, 2012). Value engineering is defined as "an organized approach to efficiently 
identify unnecessary costs" (Annappa \& Panditrao, 2012). Increasing product quality, reducing costs, eliminating wastes and improving system reliability and safety, in general, are the consequences of using this systematic, performance-based team effort (Assaf et al., 2000; Beheshti, 2004; Marzouk, 2011; Zarandi et al., 2011; Shen \& Yu, 2012). This approach attempts to enhance the value at the lowest total cost through providing the level of performance that customers expect and compliance with desired performance requirements by proper analysis of performance and cost-effective managing of different parts of a system (including quality, services, capabilities, etc.) (Shen \& Yu, 2012). This approach has been taken into consideration today due to its many capabilities and advantages in organizational management and various industries (Fong, 2004). To achieve these goals, value engineering is structured in such a way as to provide the platform for the creation of new ideas and solutions (Zhang et al., 2009) to better meet customer needs through the framework of collective innovation (Davis, 1997).

At first, value engineering was proposed for industrial production. This technique was later used in the construction industry in the 1960s (Dell'Isola, 1982; Green, 1994; Chen et al., 2010; Surlan et al., 2016; Rachwan et al., 2016). In the following years, this technique was used in other areas such as the automotive industry (Ibusuki \& Kaminski, 2007; Bock \& Pütz, 2017), manufacturing industry (Gandhinathan et al., 2004; Zengin \& Ada, 2010) and information technology industry (Tohidi, 2011; Nucciarelli et al., 2017). Examination of previous applications of this method shows that it has been used mostly at the project or organizational level (Dorvil \& Benjamin, 2002), while the authors' executive experiences show that there are many opportunities for cost reduction and improvement in supply chain level that value engineering can facilitate the path to realizing them. In other words, given that the goal of the lean paradigm and value engineering approach is to minimize cost and wastes and to eliminate non-value-adding and unnecessary functions for improving value, simultaneous application of these two methods can lead to cost reduction, increased value, and improved supply chain performance. This research is one of the first efforts to use value engineering at the supply chain level.

Furthermore, many efforts have been made to use value engineering to improve processes and reduce costs in various industries (Mahdi et al., 2015). However, despite the ability of multi-criteria decision-making methods to support decisions in this area, not enough attention has been paid to this issue (Fan et al., 2008). Azadeh et al. (2009) presented a simulation model that integrates Analytic Hierarchy Process (AHP) and Value Engineering for modelling and assessment of complex production systems with mixed queue priorities and service discipline. Marzouk (2011) presented the ELECTRE III model as an outranking model that aids in the application of value engineering in construction projects. Fazel Zarandi et al. (2011) developed a general fuzzy case based reasoning (CBR) system to assist the experts during the creativity phase of value engineering. They applied this system to suburban highway design. A review of these limited studies shows that, there are still some drawbacks to this approach. The most important of these drawbacks are as follows:

- The first problem is the overemphasis on the cost and the lack of attention to other criteria (Wao \& MQSI, 2015). Although value engineering guides the process of achieving a list of solutions, the only criteria to prioritize them are the number of views of the value engineering team members and the cost criterion. 
- Most of the stages in this method are done in groups and teams (pre-workshop, workshop and post-workshop). Although value engineering guides the process of achieving a list of solutions, the suggested method to prioritize the solutions is the number of opinions of value engineering team members (Wao \& MQSI, 2015). However, the preferences expressed by the team members are not a good basis for ranking solutions (because it cannot show the actual distance between alternatives) (Heidary Dahooie et al., 2019).

- The process of evaluating final solutions in the value engineering process, as well as other multi-criteria decision-making (MCDM) problems, usually involves uncertain information that can complicate the evaluation for decision-makers (DMs). In other words, many real-world decision-making problems occur in environments where the preference of alternatives and the weights of criteria are not exactly clear. In such circumstances, classic MCDM methods, which use definite values, do not provide sufficient and effective results (Stanujkic et al., 2017; Keshavarz Ghorabaee et al., 2018). For some reason, such as lack of access to complete information (insufficient data for decision-making), qualitative data collected, and ultimately disagreement between experts, it is sometimes necessary to use linguistic variables for decision-making. Therefore, in the value engineering process, it is also necessary to use methods that take into account the ambiguity and uncertainty in these decisions.

With this in mind, the present study attempts to present a framework for utilizing value engineering to manage costs at the supply chain level and to overcome the abovementioned drawbacks using gray number theory and combining two MCDM methods, Stepwise Weight Assessment Ratio Analysis - SWARA and Evaluation based on Distance from Average Solution - EDAS. Gray system theory is proposed to solve ambiguous problems, in case of inadequate and inaccurate information (Stanujkic et al., 2017; Keshavarz Ghorabaee et al., 2018).

Based on the proposed framework, in the value engineering study phase, the initial list of improvement solutions is identified, and the criteria for prioritization extracted from the literature are localized according to the value engineering team members' opinions. The members of the value engineering team then agree on the priority of the criteria and calculate the importance of each of these criteria based on the SWARA-Gray method. The team members then discuss the scores of each of the solutions in each criteria, and ultimately form a decision matrix by consensus. Finally, the preferences are aggregated using the EDAS-Gray method, and the prioritized solutions are considered as the input to the next step. To ensure the applicability of the proposed framework, it is implemented in a power plant company to identify and prioritize cost reduction solutions in the supply chain of cables and accessories. In order to analyze the stability of the method, the results are compared with four common gray MCDM methods.

The rest of this paper is structured as follows: Section 1 discusses the concept of Gray numbers and illustrates the SWARA-Gray and EDAS-Gray methods. The proposed methodology is discussed stepwise in Section 2. Section 3 comprises an illustrative case study for validating the proposed methodology. Section 4 show the discussion part compare the results with other common MCDM methods. Final section provides the conclusion along with future direction of this research. 


\section{Preliminaries}

\subsection{Gray numbers}

Gray system theory is one of the methods which provide the possibility of solving problems with partial information and uncertainty using mathematical analysis (Stanujkic et al., 2017). The Gray theory was first introduced by Deng in 1982 by combining the concepts of system theory, space theory, and control theory (Pan et al., 2019). This method is effective in the following cases ( $\mathrm{Wu}, 2006)$ :

- Problems with incomplete information.

- To avoid the flaws of statistical methods.

- For situations where we want to estimate uncertain system behaviour based on limited and discrete data and incomplete information.

A grey number is defined as a number whose exact value is unknown, but with a known range. Usually, a grey number is represented as a closed interval or as a set of numbers (Yazdani et al., 2019).

The following are the basics and concepts of this theory (Deng, 1982).

Consider:

$$
\otimes x=\left[\underline{x_{1}}, \overline{x_{1}}\right]=\left\{x \mid \underline{x_{1}} \leq x \leq \overline{x_{1}}, \underline{x_{1}} \text { and } x \in R\right\} .
$$

Therefore $\otimes x$ contains two real numbers of $x_{1}$ (lower limit of $\otimes x$ ) and $\overline{x_{1}}$ (upper limit of $\otimes x)$ which are defined as:

- If $x_{1} \rightarrow-\infty$ and $\overline{x_{1}} \rightarrow+\infty$ then $\otimes x$ is a black number which means that it is free of any meaningful information.

- If $x_{1}=\overline{x_{1}}$ then $\otimes x$ is a white number which means that it has complete information.

- Otherwise, $\otimes x=\left[x_{1}, \overline{x_{1}}\right]$ is a gray number which means that it contains incomplete and uncertain information.

Assume that the gray number is defined and represented by two parameters $\left[x_{1}, \overline{x_{1}}\right]$, and operators,,$+- \times$, and $\div$ represent the actions of addition, subtraction, multiplication, and division, respectively. Basic operators for gray numbers $\otimes x_{1}$ and $\otimes x_{2}$ are defined as follows:

$$
\begin{aligned}
& \otimes x_{1}+\otimes x_{2}=\left(\underline{x_{1}}+\underline{x_{2}}, \overline{x_{1}}+\overline{x_{2}}\right) ; \\
& \otimes x_{1}-\otimes x_{2}=\left(\underline{x_{1}}-\overline{x_{2}}, \overline{x_{1}}-\underline{x_{2}}\right) ; \\
& \otimes x_{1} \times \otimes x_{2}=\left(\underline{x_{1}} \times \underline{x_{2}}, \overline{x_{1}} \times \overline{x_{2}}\right) ; \\
& \otimes x_{1} \div \otimes x_{2}=\left(\frac{\underline{x_{1}}}{\overline{x_{2}}}, \frac{\overline{x_{1}}}{x_{2}}\right) ; \\
& k \times\left(\otimes x_{1}\right)=k \times\left[\underline{x_{1}}, \overline{x_{1}}\right]=\left[k x_{1}, k \overline{x_{1}}\right] .
\end{aligned}
$$




\subsection{SWARA-Gray method}

Weighting criteria is one of the most important steps in many MCDM problems (Hashemkhani Zolfani et al., 2013). Experts, therefore, play a vital role in evaluating criteria and weights, and they are an inevitable part of the decision-making process. The SWARA method is one of the newest methods developed by Kersuliene et al. in 2010 which enables decisionmakers to select, evaluate, and weight criteria (Kersuliene et al., 2010). In addition to userfriendliness, less complexity and reducing the time needed to apply (Hashemkhani Zolfani \& Saparauskas, 2013; Hashemkhani Zolfani et al., 2018; Valipour et al., 2019), one of important advantages of SWARA method is the decision maker's ability to select, evaluate, and weight indicators (Kersuliene et al., 2010; Heidary Dahooie et al., 2020). It also allows experts to apply their knowledge and experience in the relevant field (Aghdaie et al., 2014; Baušys et al., 2020). Experts can consult with each other which results in more accurate results than other MCDM methods (Dehnavi et al., 2015). It is also easy to understand and has fewer pairwise comparisons compared to methods such as Analytic Hierarchy Process (AHP) and Analytic Network Process (ANP) (Stanujkic et al., 2015).

The main steps for weighting based on the SWARA-Gray method are as follows (Mavi et al., 2018):

- Step 1: Sort the criteria.

Initially, the criteria finalized by the experts are sorted based on their degree of importance. Accordingly, the most important criterion is ranked first and the least important criterion is ranked last.

- Step 2: Determine the relative importance of each criterion $\left(S_{j}\right)$.

At this step, the relative importance of each criterion $\left(S_{j}\right)$ is determined relative to the more important one.

- Step 3: Calculate the coefficient $K_{j}$.

The coefficient $K_{j}$, which is a function of the relative importance value of each criterion, is calculated using Equation (7).

$$
K_{j}=\left\{\begin{array}{c}
{[1,1] ; j=1} \\
S_{j}+[1,1] ; j>1
\end{array} .\right.
$$

- Step 4: Calculate the initial weight of each criterion.

The initial weights of the criteria can be calculated by the Equation (8). It should be noted that the weight of the first criterion, which is the most important one, is considered to be 1 .

$$
q_{j}=\left\{\begin{array}{l}
{[1,1] ; j=1} \\
\frac{q_{j-1}}{K_{j}} ; j>1
\end{array} .\right.
$$

- Step 5: Calculate the final normal weight.

In the last step of the SWARA method, the final weights of the criteria, which are also the normalized weights, are calculated by the Equation (9). 


$$
w_{j}=\frac{q_{j}}{\sum_{j=1}^{n} q_{j}},
$$

$w_{j}$ is a gray number in the form $w_{j}=\left[w_{j} ; \overline{w_{j}}\right]$ where $w_{j}$ is the lower limit and $\overline{w_{j}}$ is the upper limit of the weight of the criterion $j$.

\subsection{EDAS-Gray method}

Evaluation Based on Distance from Average Solution (EDAS) technique was first introduced by Keshavarz Ghorabaee et al. in 2015 (Keshavarz Ghorabaee et al., 2015). In methods such as Technique for Order of Preference by Similarity to Ideal Solution (TOPSIS) or Višekriterijumsko kompromisno rangiranje (VIKOR), the best alternative is the one that has the shortest distance from the positive ideal solution and the farthest distance from the negative ideal solution. But in the EDAS method, the best solution is determined based on the distance from the average solution. In this method, there is no need to calculate the positive and negative ideal solutions, and two measures are determined for evaluating the most desirable alternative. The first measure is Positive Distance from Average (PDA) and the second one is the Negative Distance from Average (NDA). These measures can show the difference between each alternative and the average solution. Alternatives are evaluated according to the higher PDA value and lower NDA value. The alternative with the highest PDA value and lowest NDA value is the most desirable one.

The computation logic of the EDAS method is very innovative and is based on verified methods adopted in some prominent MCDM methods such as Simple Additive Weighting - SAW (Kaliszewski \& Podkopaev, 2016; MacCrimmon, 1968), TOPSIS (Yoon \& Hwang, 1995), and VIKOR (Opricovic, 1998). The EDAS method is expected to be used to solve many MCDM issues soon (Stanujkic et al., 2017). A number of papers have already been published in various fields that apply this method either in its conventional or other forms (Stević et al., 2019; Zavadskas et al., 2019; Karabasevic et al., 2018; Zhang et al., 2019; Li et al., 2020; Bielinskas et al., 2018). The EDAS method is very useful when the criteria are inconsistent and does not require an ideal and anti-ideal solution calculation (Keshavarz Ghorabaee et al., 2015).

In a decision-making problem involving $m$ alternatives and $n$ criteria, the steps of the EDAS-Gray method are as follows (Stanujkic et al., 2017).

- Step 1: The gray decision matrix is formed according to Equation (10).

$$
\otimes X=\left[\begin{array}{cccc}
{\left[\underline{x}_{11}, \bar{x}_{11}\right]} & {\left[\underline{x}_{12}, \bar{x}_{12}\right]} & \cdots & {\left[\underline{x}_{1 n}, \bar{x}_{1 n}\right]} \\
{\left[\underline{x}_{21}, \bar{x}_{21}\right]} & {\left[\underline{x}_{22}, \bar{x}_{22}\right]} & \ldots & {\left[\underline{x}_{2 n}, \bar{x}_{2 n}\right]} \\
\vdots & \vdots & \vdots & \vdots \\
{\left[\underline{x}_{m 1}, \bar{x}_{m 1}\right]} & {\left[\underline{x}_{m 2}, \bar{x}_{m 2}\right]} & \cdots & {\left[\underline{x}_{m n}, \bar{x}_{m n}\right]}
\end{array}\right] .
$$

- Step 2: The gray mean solution is determined for all criteria based on Equations (11)-(13).

$$
\otimes x_{j}^{*}=\left(\left[x_{1}^{*}, x_{1}^{*}\right]\right),\left(\left[x_{2}^{*}, x_{2}^{*}\right]\right),\left(\left[x_{n}^{*}, x_{n}^{*}\right]\right) ;
$$




$$
\begin{aligned}
& \overline{x_{j}^{*}}=\frac{\sum_{i=1}^{m} x_{i j}}{m} ; \\
& \overline{x_{j}^{*}}=\frac{\sum_{i=1}^{m} \overline{x_{i j}}}{m} .
\end{aligned}
$$

- Step 3: Positive Distance from Average (PDA) and Negative Distance from Average (NDA) matrices are calculated in terms of gray numbers according to profit and cost criteria based on Equations (14)-(17).

$$
\begin{aligned}
& \underline{d}_{i j}^{+}=\left\{\begin{array}{l}
\frac{\max \left(0,\left(\underline{x_{i j}}-\overline{x_{j}^{*}}\right)\right)}{0.5\left(\underline{x_{j}^{*}}+\overline{x_{j}^{*}}\right)} ; j \in \Omega_{\max } \\
\frac{\max \left(0,\left(\underline{x_{j}^{*}}-\overline{x_{i j}}\right)\right)}{0.5\left(\underline{x_{j}^{*}}+\overline{x_{j}^{*}}\right)} ; j \in \Omega_{\min }
\end{array} ;\right. \\
& \overline{d_{i j}^{+}}=\left\{\begin{array}{l}
\frac{\max \left(0,\left(\overline{x_{i j}}-\underline{x_{j}^{*}}\right)\right)}{0.5\left(\overline{x_{j}^{*}}+\overline{x_{j}^{*}}\right)} ; j \in \Omega_{\max } \\
\frac{\left.\max \left(0, \overline{\left(x_{j}^{*}\right.}-\overline{x_{i j}}\right)\right)}{0.5\left(\underline{x_{j}^{*}}+\overline{x_{j}^{*}}\right)} ; j \in \Omega_{\min }
\end{array} ;\right. \\
& \underline{d}_{i j}^{-}=\left\{\begin{array}{l}
\frac{\max \left(0,\left(\underline{x_{j}^{*}}-\overline{x_{i j}}\right)\right)}{0.5\left(\underline{x_{j}^{*}}+\overline{x_{j}^{*}}\right)} ; j \in \Omega_{\max } \\
\frac{\max \left(0,\left(\underline{x_{i j}}-\overline{x_{j}^{*}}\right)\right)}{0.5\left(\underline{x_{j}^{*}}+\overline{x_{j}^{*}}\right)} ; j \in \Omega_{\min }
\end{array} ;\right. \\
& \overline{d_{i j}}=\left\{\begin{array}{l}
\frac{\max \left(0,\left(\overline{x_{j}^{*}}-\underline{x_{i j}}\right)\right)}{0.5\left(\overline{x_{j}^{*}}+\overline{x_{j}^{*}}\right)} ; j \in \Omega_{\max } \\
\frac{\max \left(0, \overline{x_{i j}}-x_{j}^{*}\right)}{0.5\left(\underline{x_{j}^{*}}+\overline{x_{j}^{*}}\right)} ; j \in \Omega_{\min }
\end{array} .\right.
\end{aligned}
$$

- Step 4: The weighted sum of the positive and negative gray distances from average for all the alternatives is determined by the Equations (18)-(21). 


$$
\begin{aligned}
& \underline{Q_{i}^{+}}=\sum_{j=1}^{n} \underline{w_{j}} \underline{d_{i j}^{+}} ; \\
& \overline{Q_{i}^{+}}=\sum_{j=1}^{n} \overline{w_{j}} \overline{d_{i j}^{+}} ; \\
& \underline{Q_{i}^{-}}=\sum_{j=1}^{n} \overline{w_{j}} \underline{d_{i j}^{-}} ; \text {and } \\
& \overline{Q_{i}^{-}}=\sum_{j=1}^{n} \overline{w_{j}} \overline{d_{i j}^{-}} .
\end{aligned}
$$

- Step 5: The weighted sum of gray PDA and weighted sum of gray for each alternative is normalized based on Equations (22)-(25).

$$
\begin{aligned}
& \underline{S_{i}^{+}}=\frac{Q_{i}^{+}}{\max _{k} \overline{Q_{k}^{+}}} ; \\
& \overline{S_{i}^{+}}=\frac{\overline{Q_{i}^{+}}}{\max _{k} \overline{Q_{k}^{+}}} ; \\
& \underline{S_{i}^{-}}=1-\frac{\overline{Q_{i}^{-}}}{\max _{k} \overline{Q_{k}^{+}}} \text {and } \\
& \overline{S_{i}^{-}}=1-\frac{Q_{i}^{-}}{\max _{k} \overline{Q_{k}^{+}}} .
\end{aligned}
$$

- Step 6: The appraisal score $\left(S_{i}\right)$ is calculated for all alternatives based on Equations (26) and (27).

$$
\begin{aligned}
& S_{i}=\frac{1}{4}\left(\underline{S_{i}^{+}}+\overline{S_{i}^{+}}+\underline{S_{i}^{-}}+\overline{S_{i}^{-}}\right), \text {or } \\
& S_{i}=\frac{1}{2}\left[(1-\alpha)\left(\underline{S_{i}^{-}}+\underline{S_{i}^{+}}\right)+\alpha\left(\overline{S_{i}^{-}}+\overline{S_{i}^{+}}\right)\right] .
\end{aligned}
$$

If decision-makers want to give different importance to lower or upper bounds of the grey interval or want to perform sensitivity analysis can use parameter $\alpha$.

- Step 7: The alternatives are ranked according to their scores. The alternative with the highest value of $S_{i}$ is considered as the best alternative.

\section{Proposed methodology}

As described in the previous sections, the purpose of this paper is to provide a framework for identifying and ranking cost reduction solutions in the supply chain using a combination of a value engineering approach and MCDM methods. 
Based on the literature, value engineering studies are conducted in three stages: pre-workshop, workshop, and post-workshop (Lin et al., 2011). This process is applied in six phases of information gathering, performance analysis, creativity, evaluation, development, and presentation at the organization level (Zarandi et al., 2011; El-Nashar, 2017). In this study, we redesigned this framework to overcome pitfalls of traditional value engineering approach mentioned in the introduction.

The steps of this study are illustrated in Figure 1.

\section{Stage 1: Pre-Study}

Initially, after gathering the baseline information and defining scope and objectives, the value engineering team comprised of value engineering consultants and supply chain specialists with the necessary experience and expertise in the field was formed. The value engineering team defines, evaluates and solves value problems and challenges, develops solutions and makes decision making model (criteria, assessment scores, etc.). The value team leader leads the study team in different stages. Then, the initial list of criteria is extracted from literature review process. In the following, we prepare the model by obtaining value engineering team opinions using Fuzzy Delphi method.

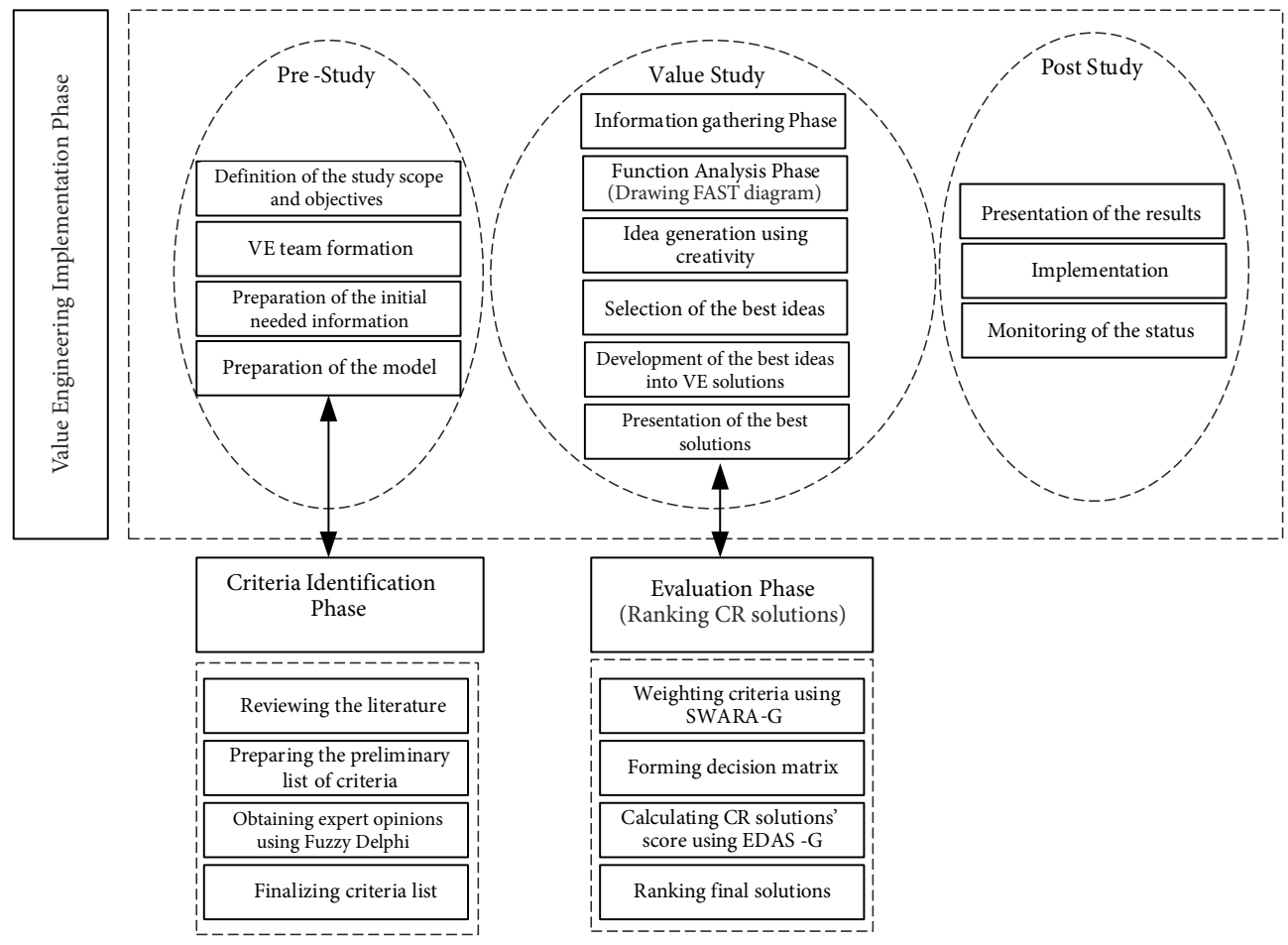

Figure 1. Research steps 


\section{Stage 2: Value Study}

In the process of studying the value engineering process, the project team, after reviewing and analyzing the information obtained from the study phase, drew up the Function Analysis System Technique (FAST) diagram of the project. Then based on the drawn FAST diagram, project team members were guided by creative techniques to present ideas. Since all the ideas presented were not applicable, the initial ideas were evaluated by experts in the value engineering team, and a list of cost reduction solutions were identified. Then, the following steps were taken to rank the identified solutions. Members of the value engineering team evaluated the value of each identified solution based on the criteria from the previous step and created the decision matrix. The importance of the criteria was calculated using the SWARA-Gray method. The EDAS-Gray method was used to rank the identified solutions and select the best one.

\section{Stage 3: Post Study}

In the third stage, the previous findings were made available to the final decision-makers (senior executives of the company), and executive suggestions were made to achieve the planned goals.

\section{Case study: prioritization of cost reduction solutions}

In this paper, a new approach is proposed to identify and prioritize cost reduction solutions in the cable and accessories supply chain of a combined cycle power plant in Iran. This hybrid cycle power plant is one of the most important power plants in Iran that plays a vital role in the power supply. This power plant was established to enhance electricity generation, respond to regional consumption growth, and utilize maximum engineering power within the country. Due to the vital role of the power plant in providing electricity and eliminating the costs associated with its supply chain, the value engineering team was formed under the leading of the company's value engineering unit manager.

With the help of an external consultant, the company's decision-makers have been implementing value engineering in various units for the past nine years. This team is a multidisciplinary group of experienced professionals and engineering consultants. Team members are chosen based on their expertise and experience in different disciplines of power plant supply chain. Main structure of value engineering team is team leader, value engineer consultant, chief power plant engineers of each discipline (electrical, mechanical, etc.). Specialist from support functions (such as HSE, quality, purchasing, legal, financial and installation) were also members of the team. In addition to having at least 10 years of experience, most members have participated in some previous value engineering sessions and have participated in several training courses in the value engineering field. Sometimes individuals who have relevant expertise; but are not directly involved with the project are added to provide a different point of view.

The value engineering team defines, evaluates and solves value problems and challenges, develops solutions and makes decision making model (criteria, assessment scores, etc.). The value team leader leads the study team in different stages, provide the necessary agreements between team members and aggregate their opinions. 
According to existing standards, value engineering was carried out in three stages. In the first stage (pre-study) data was collected, the basics of the study were explained, and the project team was formed. In the second phase (study), related workshops were devoted to the topics of creativity and idea presentation, initial evaluation and development of ideas, and providing a list of solutions. In the third stage (post-study) the main activities such as analysis of results and presenting suggestions for improvement of performance, implementation, and evaluation of results were included. Functional analysis is required according to the descriptions of the stages of implementation and execution of value engineering. Functional analysis of activities is an effective way of assessing the feasibility of executive methods to achieve the goals. The FAST diagram is used to perform functional analysis. After conducting numerous sessions, the value engineering team members designed the FAST diagram. In Figure 2, the FAST diagram of the project is plotted.

Based on the FAST diagram and the opinions of value engineering team members, cost reduction ideas were extracted. The number of ideas produced in each of the key functional features, including supervising installation, detailed design, providing items, deciding on surplus items, and testing and delivering, was 141, 71, 51, 49, 44, and 43 ideas, respectively. Many of the proposed solutions were abandoned in the evaluation phase for some reasons, such as duplicity, low applicability, the lack of consensus, being out of scope, ambiguity, and negative impact on goals. Finally, after evaluating, reviewing, and developing the initial solutions, twelve final solutions were selected by the team members to be used to reduce costs in the combined cycle power plant project. The twelve final solutions selected are described in Table 1.

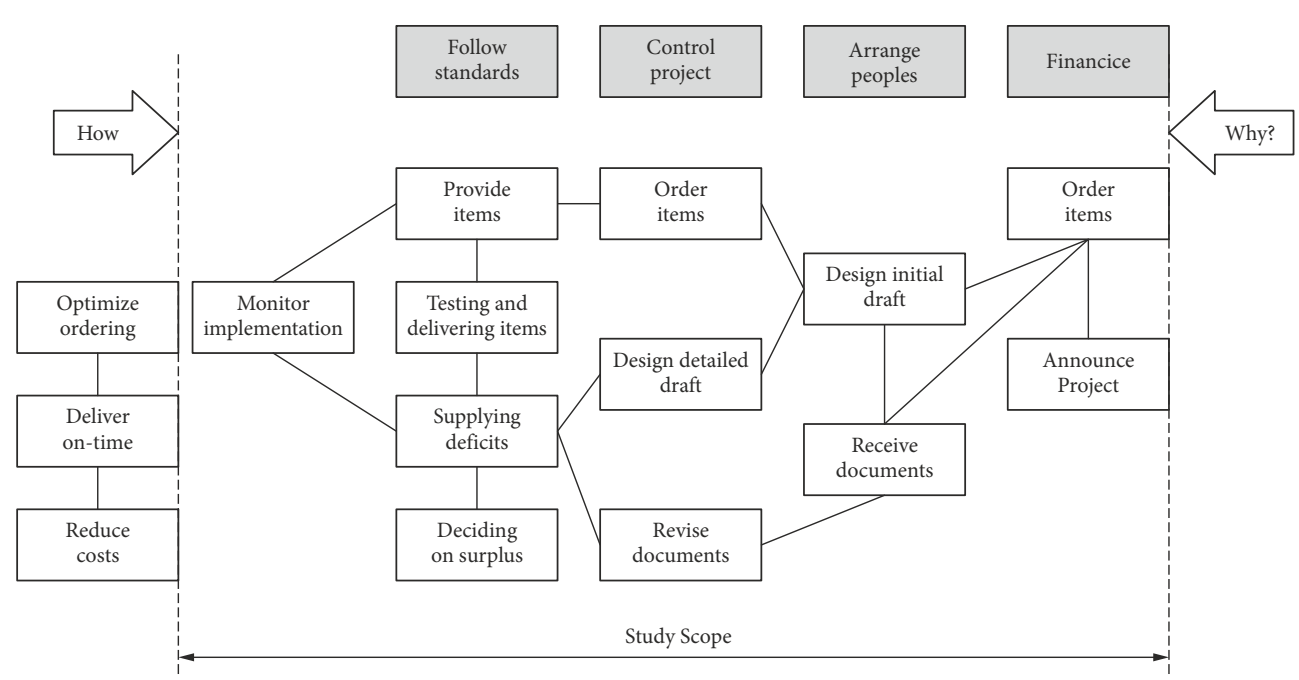

Figure 2. FAST diagram of value engineering project of power plant 
Table 1 . The final solutions identified to reduce costs in the combined cycle power supply chain

\begin{tabular}{|l|l|}
\hline \multicolumn{2}{|c|}{ The final solutions identified to reduce costs in the supply chain } \\
\hline Solution 1 & $\begin{array}{l}\text { Prevent changes in cable routing on-site without coordination with designer and } \\
\text { administrator }\end{array}$ \\
\hline Solution 2 & Design after completing the input documents \\
\hline Solution 3 & $\begin{array}{l}\text { Reduce the bureaucracy of testing equipment by reducing test personnel and testing } \\
\text { procedures and not testing cables made by a similar factory that has a test sheet }\end{array}$ \\
\hline Solution 4 & Using ELECDES software for engineering documentation \\
\hline Solution 5 & $\begin{array}{l}\text { Providing a comprehensive document by the MAPNA Engineering Department } \\
\text { indicating that the location of all the listing equipment is specified }\end{array}$ \\
\hline Solution 6 & Modification of power cable sizing criterion (duplication evaluation in Group B) \\
\hline Solution 7 & $\begin{array}{l}\text { Use software communication protocols instead of HARD WIRE communications to } \\
\text { reduce cable consumption }\end{array}$ \\
\hline Solution 8 & $\begin{array}{l}\text { Apply Design Data Freeze to the design process to estimate project financial and time } \\
\text { costs }\end{array}$ \\
\hline Solution 9 & $\begin{array}{l}\text { Modify CBS and recover costs of engineering changes after cancellation and re- } \\
\text { notification }\end{array}$ \\
\hline Solution 10 & $\begin{array}{l}\text { Creating a cable cutting system, consuming based on cutting reports, and creating } \\
\text { cutting list documents }\end{array}$ \\
\hline Solution 11 & Creating new procedures for purchasing deficit items \\
\hline Solution 12 & $\begin{array}{l}\text { Reduce the time delay between order, purchase, and delivery by modifying the } \\
\text { purchase procedure }\end{array}$ \\
\hline
\end{tabular}

\subsection{Identifying and summarizing criteria}

As stated in the methodology section, prioritizing solutions require identifying criteria based on the literature. Further, the criteria identified should be modified and localized according to the opinions of the value engineering team members. The Delphi process has been used for this purpose. The final list of criteria to evaluate solutions is categorized in Table 2.

\subsection{Calculate the final weight of sub-criteria}

In the next phase, the weight of the criteria must be calculated. According to SWARA-Gray method, in the first step, the value engineering team members were asked to assess the importance of main criteria. The results of the sorting step are shown in Table 3 first column. All team members agreed on these sorting and relative importance of each criterion.

The second to fourth steps of the SWARA-Gray method are presented in the second to forth columns of Table 3, respectively. Finally, the normalized weights of the criteria were calculated by performing the final step of the SWARA-Gray method (Eq. (9)), which is presented in the fifth column of Table 3.

Similarly, the SWARA method was used to determine the weights of the sub-criteria of performance, feasibility, applicability, effectiveness, and compliance with environmental requirements. The results are shown in Table 4. 
Table 2. The final criteria for evaluating solutions

\begin{tabular}{|l|l|l|}
\hline Main criteria & \multicolumn{1}{|c|}{ Sub-criteria } & \multicolumn{1}{c|}{ References } \\
\hline \multirow{2}{*}{$\begin{array}{l}\text { Performance } \\
\text { (A) }\end{array}$} & Cost (A1) & $\begin{array}{l}\text { Fong et al. (2007) } \\
\text { Kelly (2007) } \\
\text { Bowen et al. (2010a, 2010b) }\end{array}$ \\
\cline { 2 - 3 } & Short implementation time (A2) & $\begin{array}{l}\text { Kelly (2007) } \\
\text { Bowen et al. (2010a, 2010b) }\end{array}$ \\
\hline Feasibility (B) & Economic feasibility (B1) & Ellis et al. (2005) \\
\cline { 2 - 3 } & Technological feasibility (B2) & Ellis et al. (2005) \\
\hline $\begin{array}{l}\text { Applicability } \\
\text { (C) }\end{array}$ & Ease of implementation and safety (C1) & Fong et al. (2007) \\
\cline { 2 - 3 } & Flexibility (C2) & Bowen et al. (2010a, 2010b) \\
\hline $\begin{array}{l}\text { Effectiveness } \\
\text { (D) }\end{array}$ & Added value to the project (D1) & Bowen et al. (2010a, 2010b) \\
\cline { 2 - 3 } & Customer acceptance (D2) & Ellis et al. (2005) \\
\cline { 2 - 3 } & Compliance with company policies and politics (D3) & Bowen et al. (2010a, 2010b) \\
\hline $\begin{array}{l}\text { Compliance } \\
\text { with } \\
\text { environmental } \\
\text { requirements } \\
\text { (E) }\end{array}$ & Minimizing environmental impacts (E1) & Bowen et al. (2010a, 2010b) \\
\cline { 2 - 3 } & Considering environmental features (E2) & $\begin{array}{l}\text { Fong et al. (2007) } \\
\text { Kelly (2007) }\end{array}$ \\
\cline { 2 - 3 } & Consistency with social perceptions and beliefs (E3) & Fong et al. (2007) \\
\hline
\end{tabular}

Table 3. Calculating the weight of main criteria

\begin{tabular}{|c|c|c|c|c|c|c|c|c|}
\hline Criteria & \multicolumn{2}{|c|}{$\begin{array}{c}\text { Comparative importance } \\
\text { of average value }\left(S_{j}\right)\end{array}$} & \multicolumn{2}{c|}{$\begin{array}{c}\text { Coefficient } \\
k_{j}=S_{j}+[1 ; 1]\end{array}$} & \multicolumn{2}{c|}{$\begin{array}{c}\text { Recalculated } \\
\text { weight } q_{j}\end{array}$} & \multicolumn{2}{c|}{$\begin{array}{c}\text { Local } \\
\text { weight } w_{j}\end{array}$} \\
\hline $\mathrm{A}$ & --- & --- & 1 & 1 & 1 & 1 & 0.347 & 0.458 \\
\hline $\mathrm{D}$ & 0.326 & 1 & 1.326 & 2 & 0.5 & 0.754 & 0.173 & 0.345 \\
\hline $\mathrm{B}$ & 0.234 & 0.324 & 1.234 & 1.324 & 0.378 & 0.611 & 0.131 & 0.28 \\
\hline $\mathrm{C}$ & 0.176 & 0.235 & 1.176 & 1.235 & 0.306 & 0.52 & 0.106 & 0.238 \\
\hline $\mathrm{E}$ & 0.135 & 0.186 & 1.135 & 1.186 & 0.258 & 0.458 & 0.089 & 0.21 \\
\hline
\end{tabular}

Table 4. Calculating performance sub-criteria weights

\begin{tabular}{|c|c|c|c|c|c|c|c|c|c|c|}
\hline $\begin{array}{c}\text { Sub- } \\
\text { criteria }\end{array}$ & $\begin{array}{c}\text { Comparative } \\
\text { importance of } \\
\text { average value }\left(S_{j}\right)\end{array}$ & $\begin{array}{c}\text { Coefficient } \\
k_{j}=S_{j}+[1 ; 1]\end{array}$ & $\begin{array}{c}\text { Recalculated } \\
\text { weight } q_{j}\end{array}$ & \multicolumn{2}{c|}{$\begin{array}{c}\text { Local } \\
\text { weight } w_{j}\end{array}$} & \multicolumn{2}{c|}{$\begin{array}{c}\text { Final } \\
\text { weight }\end{array}$} \\
\hline \multicolumn{10}{c|}{ Main criteria: Performance (A) } \\
\hline $\mathrm{A}_{1}$ & --- & --- & 1.000 & 1.000 & 1.000 & 1.000 & 0.638 & 0.651 & 0.221 & 0.298 \\
\hline $\mathrm{A}_{2}$ & 0.762 & 0.866 & 1.762 & 1.866 & 0.536 & 0.568 & 0.342 & 0.370 & 0.119 & 0.169 \\
\hline \multicolumn{10}{|c|}{ Main criteria: Feasibility (B) } \\
\hline $\mathrm{B}_{1}$ & --- & --- & 1.000 & 1.000 & 1.000 & 1.000 & 0.569 & 0.607 & 0.075 & 0.170 \\
\hline $\mathrm{B}_{2}$ & 0.321 & 0.543 & 1.321 & 1.543 & 0.648 & 0.757 & 0.369 & 0.459 & 0.048 & 0.129 \\
\hline
\end{tabular}


End of Table 4

\begin{tabular}{|c|c|c|c|c|c|c|c|c|c|c|c|}
\hline $\begin{array}{c}\text { Sub- } \\
\text { criteria }\end{array}$ & $\begin{array}{c}\text { Comparative } \\
\text { importance of } \\
\text { average value }\left(S_{j}\right)\end{array}$ & $\begin{array}{c}\text { Coefficient } \\
k_{j}=S_{j}+[1 ; 1]\end{array}$ & $\begin{array}{c}\text { Recalculated } \\
\text { weight } q_{j}\end{array}$ & \multicolumn{2}{c|}{$\begin{array}{c}\text { Local } \\
\text { weight } w_{j}\end{array}$} & \multicolumn{2}{c|}{$\begin{array}{c}\text { Final } \\
\text { weight }\end{array}$} \\
\hline \multicolumn{8}{|c|}{ Main criteria: Applicability (C) } \\
\hline $\mathrm{C}_{1}$ & --- & --- & 1.000 & 1.000 & 1.000 & 1.000 & 0.593 & 0.613 & 0.063 & 0.146 \\
\hline $\mathrm{C}_{2}$ & 0.456 & 0.582 & 1.456 & 1.582 & 0.632 & 0.687 & 0.375 & 0.421 & 0.040 & 0.100 \\
\hline \multicolumn{8}{|c|}{ Main criteria: Effectiveness (D) } \\
\hline $\mathrm{D}_{1}$ & --- & --- & 1.000 & 1.000 & 1.000 & 1.000 & 0.455 & 0.483 & 0.079 & 0.166 \\
\hline $\mathrm{D}_{2}$ & 0.456 & 0.582 & 1.456 & 1.582 & 0.632 & 0.687 & 0.288 & 0.331 & 0.050 & 0.114 \\
\hline $\mathrm{D}_{3}$ & 0.345 & 0.436 & 1.345 & 1.436 & 0.440 & 0.511 & 0.200 & 0.246 & 0.035 & 0.085 \\
\hline \multicolumn{8}{|c|}{ Main criteria: Compliance with environmental requirements (E) } \\
\hline $\mathrm{E}_{1}$ & --- & --- & 1.000 & 1.000 & 1.000 & 1.000 & 0.503 & 0.523 & 0.045 & 0.110 \\
\hline $\mathrm{E}_{2}$ & 0.657 & 0.768 & 1.657 & 1.768 & 0.566 & 0.604 & 0.284 & 0.316 & 0.025 & 0.066 \\
\hline $\mathrm{E}_{3}$ & 0.563 & 0.632 & 1.563 & 1.632 & 0.347 & 0.386 & 0.174 & 0.202 & 0.016 & 0.042 \\
\hline
\end{tabular}

\subsection{Prioritizing the final CR solutions to supply chain}

To prioritize the identified solutions, members of the value engineering team were asked to evaluate alternatives in each sub-criteria using linguistic variables presented in Table 5. To this aim, team members held discussions on the scores of each solution in each one of the final criteria and formed a decision matrix by consensus.

The evaluation of the solutions is presented in Table 6 .

Now convert the linguistic variables in Table 6 to gray numbers by using Table 5 to obtain the final decision matrix in gray numbers. In the next step, the grey average solution obtained by using Eqs (12) and (13). Then, the PDA and NDA matrices were determined according to the criteria types by using Eqs (14) to (17). The results are shown in Tables 7 and 8 , respectively.

Table 5. Linguistic variables corresponding to gray numbers (Turskis \& Zavadskas, 2010)

\begin{tabular}{|l|c|}
\hline \multicolumn{1}{|c|}{ Linguistic variables } & Gray numbers \\
\hline Very Low $(\mathrm{VL})$ & $(0,0.2)$ \\
\hline Low $(\mathrm{L})$ & $(0.1,0.3)$ \\
\hline Medium Low $(\mathrm{ML})$ & $(0.2,0.4)$ \\
\hline Medium $(\mathrm{M})$ & $(0.35,0.65)$ \\
\hline Medium High $(\mathrm{MH})$ & $(0.6,0.8)$ \\
\hline High $(\mathrm{H})$ & $(0.7,0.9)$ \\
\hline Very High $(\mathrm{VH})$ & $(0.8,1)$ \\
\hline
\end{tabular}


Table 6. Final decision matrix evaluated by linguistic variables in terms of gray numbers

\begin{tabular}{|c|c|c|c|c|c|c|c|c|c|c|c|c|}
\hline Sub-criteria & $\overrightarrow{4}$ & \& & $\omega^{-1}$ & $\infty^{N}$ & $v$ & $v^{N}$ & $\bar{a}$ & $a^{N}$ & $a^{m}$ & બ્山 & N & भी \\
\hline $\begin{array}{l}\text { Type of the } \\
\text { criterion }\end{array}$ & $\overrightarrow{0}$ & 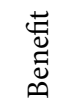 & 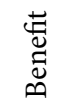 & 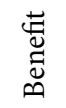 & $\begin{array}{l}\text { 苛 } \\
\text { ڤ్ } \\
\infty\end{array}$ & 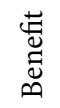 & 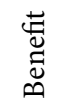 & 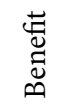 & 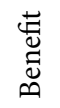 & 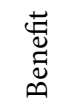 & 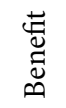 & 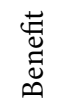 \\
\hline Weight & 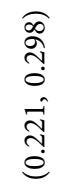 & $\begin{array}{l}\hat{\sigma} \\
\overrightarrow{0} \\
0 \\
\hat{a} \\
\overrightarrow{0}\end{array}$ & $\begin{array}{l}\widehat{O} \\
\stackrel{0}{0} \\
0 \\
10 \\
0 \\
0 \\
0\end{array}$ & 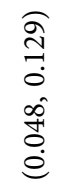 & $\begin{array}{l}\widehat{0} \\
\stackrel{+}{1} \\
\dot{0} \\
\dot{0} \\
\dot{0} \\
\dot{0} \\
\dot{0}\end{array}$ & $\begin{array}{l}\widehat{8} \\
\dot{0} \\
0 \\
0 \\
0 \\
0 \\
0 \\
0\end{array}$ & $\begin{array}{l}\widehat{0} \\
\stackrel{0}{0} \\
-1 \\
0 \\
\hat{0} \\
0 \\
0\end{array}$ & 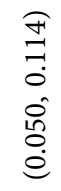 & $\begin{array}{l}\widehat{1} \\
0 \\
0 \\
0 \\
0 \\
\hat{n} \\
0 \\
0 \\
\dot{0}\end{array}$ & $\begin{array}{l}\widehat{O} \\
\exists \\
\overrightarrow{0} \\
0 \\
\dot{0} \\
0 \\
\dot{0}\end{array}$ & 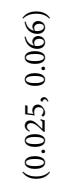 & 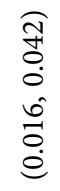 \\
\hline Solution 1 & $\mathrm{H}$ & $\mathrm{H}$ & $\mathrm{VH}$ & $\mathrm{VH}$ & $\mathrm{VH}$ & $\mathrm{L}$ & $\mathrm{VH}$ & $\mathrm{VH}$ & $\mathrm{VH}$ & $\mathrm{M}$ & $\mathrm{M}$ & ML \\
\hline Solution 2 & $\mathrm{VH}$ & $\mathrm{VH}$ & $\mathrm{VH}$ & $\mathrm{VH}$ & $\mathrm{VH}$ & ML & $\mathrm{VH}$ & $\mathrm{VH}$ & $\mathrm{VH}$ & $M$ & $\mathrm{MH}$ & ML \\
\hline Solution 3 & $\mathrm{H}$ & $\mathrm{VH}$ & $\mathrm{VH}$ & $\mathrm{H}$ & $\mathrm{VH}$ & ML & $\mathrm{H}$ & $\mathrm{VH}$ & $\mathrm{VH}$ & $\mathrm{M}$ & $\mathrm{M}$ & $\mathrm{M}$ \\
\hline Solution 4 & $\mathrm{VH}$ & $\mathrm{VH}$ & $\mathrm{VH}$ & $\mathrm{VH}$ & $\mathrm{VH}$ & ML & $\mathrm{VH}$ & $\mathrm{VH}$ & $\mathrm{VH}$ & $\mathrm{H}$ & ML & $\mathrm{L}$ \\
\hline Solution 5 & $\mathrm{H}$ & $\mathrm{H}$ & $\mathrm{H}$ & $\mathrm{H}$ & $\mathrm{MH}$ & ML & $\mathrm{H}$ & $\mathrm{VH}$ & $\mathrm{VH}$ & $\mathrm{H}$ & $\mathrm{M}$ & $\mathrm{L}$ \\
\hline Solution 6 & $\mathrm{VH}$ & $\mathrm{H}$ & $\mathrm{VH}$ & $\mathrm{VH}$ & $\mathrm{VH}$ & $\mathrm{ML}$ & $\mathrm{H}$ & $\mathrm{VH}$ & $\mathrm{VH}$ & $\mathrm{MH}$ & $\mathrm{ML}$ & ML \\
\hline Solution 7 & $\mathrm{VH}$ & $\mathrm{VH}$ & $\mathrm{H}$ & $\mathrm{VH}$ & $\mathrm{H}$ & ML & $\mathrm{VH}$ & $\mathrm{VH}$ & $\mathrm{VH}$ & $\mathrm{H}$ & $\mathrm{ML}$ & $\mathrm{L}$ \\
\hline Solution 8 & $\mathrm{VH}$ & $\mathrm{VH}$ & $\mathrm{VH}$ & $\mathrm{H}$ & $\mathrm{H}$ & $\mathrm{H}$ & $\mathrm{H}$ & $\mathrm{VH}$ & $\mathrm{H}$ & $\mathrm{H}$ & $\mathrm{M}$ & $\mathrm{L}$ \\
\hline Solution 9 & $\mathrm{VH}$ & $\mathrm{VH}$ & $\mathrm{VH}$ & $\mathrm{VH}$ & $\mathrm{VH}$ & ML & $\mathrm{VH}$ & ML & $\mathrm{VH}$ & $\mathrm{H}$ & ML & $\mathrm{L}$ \\
\hline Solution 10 & $\mathrm{VH}$ & $\mathrm{H}$ & $\mathrm{MH}$ & $\mathrm{VH}$ & $\mathrm{H}$ & ML & $\mathrm{VH}$ & $\mathrm{VH}$ & $\mathrm{VH}$ & $\mathrm{MH}$ & $\mathrm{MH}$ & $\mathrm{M}$ \\
\hline Solution 11 & $\mathrm{H}$ & $\mathrm{H}$ & $\mathrm{H}$ & $\mathrm{H}$ & $\mathrm{H}$ & $\mathrm{ML}$ & $\mathrm{H}$ & $\mathrm{VH}$ & $\mathrm{VH}$ & $\mathrm{M}$ & $\mathrm{M}$ & $\mathrm{M}$ \\
\hline Solution 12 & $\mathrm{H}$ & $\mathrm{VH}$ & $\mathrm{VH}$ & $\mathrm{VH}$ & $\mathrm{H}$ & $\mathrm{H}$ & $\mathrm{VH}$ & $\mathrm{VH}$ & $\mathrm{VH}$ & $\mathrm{MH}$ & $\mathrm{MH}$ & $\mathrm{MH}$ \\
\hline
\end{tabular}

In the next step, the weighted and normalized weighted grey sums of positive and negative distances from the average were determined by using Eqs (18) to (25). The results are shown in Table 9.

Finally, the estimated score $\left(S_{i}\right)$ is calculated for all alternatives by using Eq. (26). Table 10 shows the final scores and ranking of alternatives.

As the results of prioritization with the EDAS-Gray method show, solution 12 (Reduce order time to purchase and delivery by modifying the purchase procedure), solution 8 (Apply Design Data Freeze to the design process to estimate project financial and time costs), and solution 2 (Design after completing the input documents) are chosen as the best, respectively.

\section{Comparison and discussion}

In order to analyze the stability of the method used, the results of the EDAS-Gray method are compared with the results of the Gray Simple Additive Weighting (SAW-Gray) (Zavadskas et al., 2010), Gray Technique for Order of Preference by Similarity to Ideal Solution (TOPSIS-Gray) (Jahanshahloo et al., 2006), Gray Additive Ratio Assessment (ARAS-Gray) (Turskis \& Zavadskas, 2010) and Gray COmplex PRoportional ASsessment of alternatives (COPRAS_Gray) (Kildienè et al., 2011). These methods are commonly used MCDM methods for ranking alternatives. 


\begin{tabular}{|c|c|c|c|c|c|c|c|c|c|c|c|c|}
\hline \multirow{2}{*}{ ફ્યી } & $\ddot{n}$ & $\tilde{0}$ & $\stackrel{\widetilde{\sim}}{\rightarrow}$ & $\begin{array}{l}\text { 今े } \\
\text { ஸे }\end{array}$ & $\begin{array}{l}\text { 今ે } \\
\text { ֶ̦ }\end{array}$ & $\stackrel{2}{0}$ & $\begin{array}{l}\text { 今ે } \\
\text { ஸ̣ }\end{array}$ & $\begin{array}{l}\text { ָे } \\
\text { ọ }\end{array}$ & $\begin{array}{l}\text { 今ે } \\
\text { ஸ̣ }\end{array}$ & 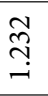 & $\widetilde{\widetilde{N}}$ & $\stackrel{-}{\hat{\sigma}}$ \\
\hline & 0 & 0 & 0 & 0 & 0 & 0 & 0 & 0 & 0 & 0 & 0 & 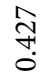 \\
\hline \multirow[t]{2}{*}{ ર્ગે } & $\begin{array}{l}n \\
\hat{\sigma} \\
0 \\
0\end{array}$ & $\begin{array}{l}\stackrel{n}{\circ} \\
\vdots \\
0\end{array}$ & $\begin{array}{l}n \\
\hat{n} \\
0 \\
0\end{array}$ & $\begin{array}{l}\infty \\
\stackrel{0}{0} \\
0\end{array}$ & $\begin{array}{l}n \\
\hat{n} \\
0 \\
0\end{array}$ & $\begin{array}{l}\infty \\
\stackrel{\infty}{0} \\
0\end{array}$ & $\begin{array}{l}\infty \\
\stackrel{\infty}{0} \\
0\end{array}$ & $\begin{array}{l}\text { Ln } \\
\text { గn }\end{array}$ & $\begin{array}{l}\infty \\
\stackrel{\infty}{0} \\
0\end{array}$ & $\begin{array}{l}\stackrel{2}{\circ} \\
\stackrel{0}{0}\end{array}$ & $\begin{array}{l}n \\
\hat{\alpha} \\
0\end{array}$ & 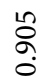 \\
\hline & 0 & 0 & 0 & 0 & 0 & 0 & 0 & 0 & 0 & 0 & 0 & 0 \\
\hline \multirow{2}{*}{ બ્ય } & $\begin{array}{l}0 \\
\stackrel{\sim}{0} \\
\stackrel{0}{0}\end{array}$ & $\begin{array}{l}0 \\
\stackrel{m}{0} \\
-\end{array}$ & $\begin{array}{l}0 \\
\stackrel{9}{0} \\
\stackrel{0}{0}\end{array}$ & $\begin{array}{l}0 \\
\text { 1n } \\
0\end{array}$ & $\begin{array}{l}0 \\
0 \\
1+0 \\
0\end{array}$ & 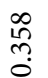 & $\begin{array}{l}0 \\
0 \\
1+0 \\
0\end{array}$ & $\begin{array}{l}0 \\
\text { in } \\
0\end{array}$ & $\begin{array}{l}\text { ?: } \\
\text { in }\end{array}$ & 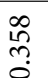 & $\begin{array}{l}0 \\
\stackrel{2}{0} \\
0\end{array}$ & $\begin{array}{l}\infty \\
1 \\
n \\
n \\
0\end{array}$ \\
\hline & 0 & 0 & 0 & 0 & 0 & 0 & 0 & 0 & 0 & 0 & 0 & 0 \\
\hline \multirow{2}{*}{$a^{m}$} & $\ddot{n}$ & $\ddot{n}$ & $\underset{\sim}{\stackrel{\sim}{\sim}}$ & 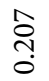 & $\begin{array}{l}\hat{\overbrace{}} \\
\text { ஸ̦ }\end{array}$ & $\stackrel{1}{0}$ & $\begin{array}{l}\hat{~} \\
\text { ஸे }\end{array}$ & $\begin{array}{l}\hat{O} \\
\text { م̦ }\end{array}$ & $\begin{array}{l}\hat{~} \\
\text { ஸे }\end{array}$ & 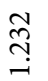 & $\stackrel{\widetilde{N}}{\sim}$ & 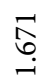 \\
\hline & 0 & 0 & 0 & 0 & 0 & 0 & 0 & 0 & 0 & 0 & 0 & 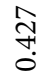 \\
\hline \multirow[t]{2}{*}{$\tilde{a}^{N}$} & 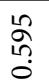 & $\begin{array}{l}\text { ஜ̊ } \\
\text { ळे }\end{array}$ & 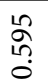 & $\begin{array}{l}\infty \\
\stackrel{\infty}{0} \\
0\end{array}$ & 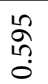 & $\begin{array}{l}\infty \\
\stackrel{\infty}{0} \\
0\end{array}$ & $\begin{array}{l}\infty \\
\stackrel{\infty}{0} \\
0\end{array}$ & $\begin{array}{l}\text { Ln } \\
\text { in }\end{array}$ & $\begin{array}{l}\infty \\
\stackrel{\infty}{0} \\
0\end{array}$ & $\begin{array}{l}\text { Lे } \\
\stackrel{\circ}{0}\end{array}$ & $\begin{array}{l}n \\
\alpha \\
n \\
0\end{array}$ & 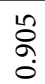 \\
\hline & 0 & 0 & 0 & 0 & 0 & 0 & 0 & 0 & 0 & 0 & 0 & 0 \\
\hline \multirow[t]{2}{*}{$\vec{a}$} & $\begin{array}{l}0 \\
\stackrel{m}{0} \\
0\end{array}$ & $\begin{array}{l}0 \\
\stackrel{0}{0} \\
0\end{array}$ & $\begin{array}{l}0 \\
\stackrel{0}{0} \\
0\end{array}$ & $\begin{array}{l}0 \\
\stackrel{1}{n} \\
0\end{array}$ & $\begin{array}{l}0 \\
: \\
1+0 \\
0\end{array}$ & $\begin{array}{l}\infty \\
\stackrel{\infty}{\omega} \\
\tilde{0}\end{array}$ & $\begin{array}{l}0 \\
0 \\
1+0 \\
0\end{array}$ & $\begin{array}{l}0 \\
0 \\
1 \\
0\end{array}$ & $\begin{array}{l}0 \\
: \\
1+1 \\
0\end{array}$ & 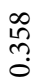 & $\begin{array}{l}0 \\
\\
0\end{array}$ & $\begin{array}{c}\infty \\
n \\
n \\
0\end{array}$ \\
\hline & 0 & 0 & 0 & 0 & 0 & 0 & 0 & 0 & 0 & 0 & 0 & 0 \\
\hline \multirow{2}{*}{$\mathcal{v}^{N}$} & $\begin{array}{l}\hat{o} \\
\dot{0}\end{array}$ & 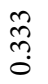 & 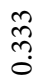 & $\underset{\stackrel{m}{m}}{\stackrel{m}{0}}$ & 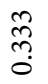 & 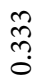 & 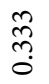 & $\overbrace{0}^{\hat{O}}$ & 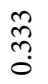 & $\underset{\overbrace{}}{\stackrel{m}{0}}$ & 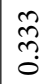 & 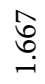 \\
\hline & 0 & 0 & 0 & 0 & 0 & 0 & 0 & $\stackrel{0}{0}$ & 0 & 0 & 0 & $\stackrel{0}{0}$ \\
\hline \multirow[t]{2}{*}{$\vec{u}$} & $\begin{array}{l}\hat{0} \\
\text { లn } \\
0\end{array}$ & $\begin{array}{l}\hat{0} \\
\text { లn }\end{array}$ & $\begin{array}{l}\hat{0} \\
\text { m. } \\
0\end{array}$ & $\begin{array}{l}\hat{0} \\
\text { m. } \\
0\end{array}$ & $\begin{array}{l}\hat{b} \\
\dot{0}\end{array}$ & $\begin{array}{l}\hat{0} \\
\text { m. } \\
0\end{array}$ & $\begin{array}{l}\infty \\
\infty \\
\stackrel{1}{0}\end{array}$ & $\begin{array}{l}\infty \\
\stackrel{\infty}{-1} \\
0\end{array}$ & $\begin{array}{l}\hat{0} \\
\text { m. } \\
0\end{array}$ & $\begin{array}{l}\infty \\
\stackrel{\infty}{-1} \\
0\end{array}$ & $\begin{array}{l}\infty \\
\infty \\
0 \\
0\end{array}$ & $\begin{array}{l}\infty \\
\infty \\
\stackrel{-}{0}\end{array}$ \\
\hline & 0 & 0 & 0 & 0 & 0 & 0 & 0 & 0 & 0 & 0 & 0 & 0 \\
\hline \multirow[t]{2}{*}{$\infty^{2}$} & $\begin{array}{l}\text { ڤे } \\
\text { ஸे }\end{array}$ & $\begin{array}{l}\text { ठे } \\
\text { ஸे }\end{array}$ & $\begin{array}{l}\text { H. } \\
\text { 号 }\end{array}$ & $\begin{array}{l}\text { oे } \\
\text { ஸे }\end{array}$ & $\begin{array}{l}\text { H. } \\
\stackrel{0}{0}\end{array}$ & $\begin{array}{l}\hat{\mathrm{o}} \\
\text { ஸे }\end{array}$ & $\begin{array}{l}\text { oे } \\
\text { ஸे }\end{array}$ & 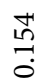 & $\begin{array}{l}\hat{\mathrm{o}} \\
\text { ஸे }\end{array}$ & $\begin{array}{l}\text { ठे } \\
\text { ஸे }\end{array}$ & $\begin{array}{l}\text { 苟 } \\
0\end{array}$ & $\begin{array}{l}\hat{0} \\
\text { ஸे }\end{array}$ \\
\hline & 0 & 0 & 0 & 0 & 0 & 0 & 0 & 0 & 0 & 0 & 0 & 0 \\
\hline \multirow[t]{2}{*}{$\overrightarrow{\varphi^{\prime}}$} & 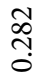 & 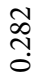 & $\begin{array}{l}\widetilde{D} \\
\underset{0}{0} \\
0\end{array}$ & 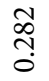 & $\begin{array}{l}n \\
\stackrel{1}{0} \\
0\end{array}$ & $\begin{array}{l}\stackrel{\infty}{0} \\
\stackrel{1}{0}\end{array}$ & $\begin{array}{l}n \\
0 \\
0\end{array}$ & $\begin{array}{l}\stackrel{\infty}{0} \\
\stackrel{1}{0}\end{array}$ & $\begin{array}{l}\stackrel{\infty}{0} \\
\stackrel{1}{0}\end{array}$ & $\begin{array}{l}\text { gे } \\
\text { Oे }\end{array}$ & $\begin{array}{l}10 \\
0 \\
0\end{array}$ & $\begin{array}{l}\text { õ } \\
\stackrel{1}{0}\end{array}$ \\
\hline & 0 & 0 & 0 & 0 & 0 & 0 & 0 & 0 & 0 & 0 & 0 & 0 \\
\hline \multirow[t]{2}{*}{ \& } & $\begin{array}{l}n \\
\stackrel{2}{0} \\
0\end{array}$ & 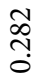 & 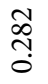 & 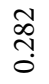 & $\begin{array}{l}\stackrel{1}{0} \\
\stackrel{1}{0}\end{array}$ & $\begin{array}{l}\stackrel{1}{0} \\
\stackrel{1}{0}\end{array}$ & 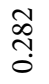 & 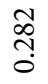 & 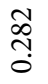 & $\begin{array}{l}n 2 \\
\stackrel{0}{0} \\
0\end{array}$ & $\begin{array}{l}n \\
0 \\
0\end{array}$ & 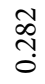 \\
\hline & 0 & 0 & 0 & 0 & 0 & 0 & 0 & 0 & 0 & 0 & 0 & 0 \\
\hline \multirow[t]{2}{*}{$\vec{\pi}$} & $\begin{array}{l}\overrightarrow{0} \\
\text { m. } \\
0\end{array}$ & $\begin{array}{l}\vec{\infty} \\
\overrightarrow{0}\end{array}$ & $\begin{array}{l}\overrightarrow{0} \\
\text { m. } \\
0\end{array}$ & $\begin{array}{l}\stackrel{\infty}{\infty} \\
\end{array}$ & $\begin{array}{l}\overrightarrow{0} \\
\text { n. } \\
0\end{array}$ & $\begin{array}{l}+ \\
\stackrel{\infty}{0} \\
0\end{array}$ & $\begin{array}{l}+\infty \\
\stackrel{\infty}{0}\end{array}$ & $\frac{\infty}{\stackrel{\infty}{\circ}}$ & $\begin{array}{l}+ \\
\stackrel{\infty}{0} \\
0\end{array}$ & $\begin{array}{l}\vec{\infty} \\
\stackrel{0}{0}\end{array}$ & $\begin{array}{l}\tilde{0} \\
\tilde{n} \\
0\end{array}$ & $\begin{array}{l}\tilde{0} \\
\text { ñ }\end{array}$ \\
\hline & 0 & 0 & 0 & 0 & 0 & 0 & 0 & 0 & 0 & 0 & 0 & 0 \\
\hline 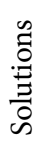 & $\begin{array}{l}\vec{\Xi} \\
\stackrel{0}{\Xi} \\
\text { 苛 }\end{array}$ & $\begin{array}{l}\text { N } \\
\stackrel{0}{0} \\
\stackrel{\Xi}{0} \\
\dot{\infty}\end{array}$ & $\begin{array}{l}\text { n } \\
\stackrel{0}{0} \\
\stackrel{\Xi}{0} \\
\stackrel{0}{0}\end{array}$ & 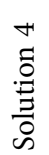 & 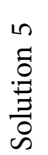 & $\begin{array}{l}0 \\
\tilde{0} \\
\stackrel{0}{\Xi} \\
0 \\
\dot{0}\end{array}$ & $\begin{array}{l}\stackrel{\Xi}{0} \\
\stackrel{0}{\Xi} \\
\stackrel{0}{0}\end{array}$ & 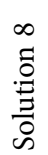 & $\begin{array}{l}a \\
\stackrel{0}{0} \\
\stackrel{\Xi}{0} \\
\stackrel{0}{0}\end{array}$ & 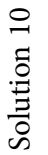 & $\begin{array}{l}= \\
\tilde{0} \\
. \Xi \\
\Xi \\
0 \\
0\end{array}$ & 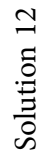 \\
\hline
\end{tabular}




\begin{tabular}{|c|c|c|c|c|c|c|c|c|c|c|c|c|}
\hline \multirow[t]{2}{*}{ ન્રી } & $\begin{array}{l}\text { 志 } \\
\text { م. }\end{array}$ & \begin{tabular}{l}
\multirow{H}{*}{} \\
$\stackrel{2}{0}$
\end{tabular} & $\begin{array}{l}\text { Ln } \\
\text { mె } \\
0\end{array}$ & ô & ڤે & \begin{tabular}{l}
\multirow{H}{*}{} \\
$\stackrel{0}{0}$
\end{tabular} & ô & ô & $\widehat{\widehat{o}}$ & $\begin{array}{l}n \\
\text { nn } \\
0\end{array}$ & $\begin{array}{l}n \\
\text { nn } \\
0\end{array}$ & 0 \\
\hline & 0 & 0 & 0 & 0 & 0 & 0 & 0 & 0 & 0 & 0 & 0 & 0 \\
\hline \multirow[t]{2}{*}{ ન્રે } & $\begin{array}{l}\text { ? } \\
\text { ñ } \\
0\end{array}$ & $\begin{array}{l}0 \\
\text { oे }\end{array}$ & $\begin{array}{l}0 \\
\text { గn } \\
0\end{array}$ & $\begin{array}{l}0 \\
\infty \\
\infty \\
0\end{array}$ & $\begin{array}{l}0 \\
\tilde{N} \\
\tilde{n}\end{array}$ & $\begin{array}{l}0 \\
\infty \\
\infty \\
0\end{array}$ & $\begin{array}{l}0 \\
\infty \\
\infty \\
0\end{array}$ & 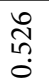 & $\begin{array}{l}0 \\
\infty \\
\infty \\
0\end{array}$ & $\begin{array}{l}0 \\
\dot{0} \\
\dot{0}\end{array}$ & $\begin{array}{l}0 \\
\text { గn } \\
0\end{array}$ & $\begin{array}{l}\hat{8} \\
\dot{0}\end{array}$ \\
\hline & 0 & 0 & 0 & 0 & 0 & 0 & 0 & 0 & 0 & 0 & 0 & 0 \\
\hline \multirow[t]{2}{*}{ F્ર } & $\begin{array}{l}+1 \\
6 \\
0 \\
0 \\
0\end{array}$ & $\begin{array}{l}\text { H' } \\
\qquad 0 \\
0\end{array}$ & $\begin{array}{l}\text { H' } \\
\qquad 0 \\
0\end{array}$ & $\begin{array}{l}0 \\
\stackrel{0}{0} \\
0\end{array}$ & $\begin{array}{l}0 \\
m \\
0 \\
0\end{array}$ & $\begin{array}{l}\stackrel{+}{0} \\
\stackrel{0}{0} \\
\stackrel{2}{0}\end{array}$ & $\begin{array}{l}0 \\
\stackrel{0}{0} \\
0\end{array}$ & $\begin{array}{l}0 \\
\stackrel{0}{0} \\
0\end{array}$ & 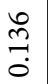 & $\begin{array}{l}+ \\
\stackrel{\infty}{0} \\
\stackrel{0}{0}\end{array}$ & $\begin{array}{l}\text { H' } \\
6 \\
0 \\
0\end{array}$ & 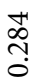 \\
\hline & 0 & 0 & 0 & 0 & 0 & 0 & 0 & 0 & 0 & 0 & 0 & 0 \\
\hline \multirow[t]{2}{*}{$a^{m}$} & 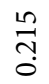 & 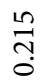 & 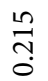 & 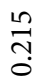 & $\begin{array}{l}n \\
\stackrel{n}{N}\end{array}$ & 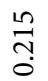 & 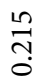 & 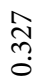 & 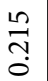 & $\begin{array}{l}\stackrel{n}{n} \\
\stackrel{n}{0}\end{array}$ & $\begin{array}{l}\stackrel{10}{n} \\
\stackrel{0}{0}\end{array}$ & 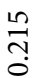 \\
\hline & 0 & 0 & 0 & 0 & 0 & 0 & 0 & 0 & 0 & 0 & 0 & 0 \\
\hline \multirow{3}{*}{$\Omega^{N}$} & $\stackrel{0}{2}$ & $\stackrel{\circ}{\stackrel{2}{*}}$ & $\stackrel{\circ}{\stackrel{1}{*}}$ & 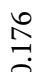 & $\stackrel{0}{2}$ & $\stackrel{\circ}{\stackrel{2}{*}}$ & 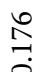 & 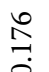 & $\begin{array}{l}\tilde{D} \\
\infty \\
\infty \\
0\end{array}$ & $\stackrel{0}{\stackrel{2}{2}}$ & $\stackrel{0}{\stackrel{2}{0}}$ & $\stackrel{\circ}{\rightleftharpoons}$ \\
\hline & & & & & & & & & & & & \\
\hline & 0 & 0 & 0 & 0 & 0 & 0 & 0 & 0 & $\stackrel{\vec{H}}{\circ}$ & 0 & 0 & 0 \\
\hline \multirow{2}{*}{$\theta^{-1}$} & $\underset{\infty}{+\infty}$ & $\stackrel{+}{\infty}$ & స్వి & $\stackrel{+}{\infty}$ & $\overrightarrow{0}$ & 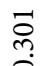 & $\stackrel{+}{\infty}$ & $\vec{\rho}$ & $\begin{array}{l}+ \\
\infty \\
-1\end{array}$ & $\stackrel{+}{\infty}$ & 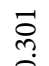 & $\stackrel{+}{\infty}$ \\
\hline & 0 & 0 & 0 & 0 & 0 & 0 & 0 & 0 & 0 & 0 & 0 & 0 \\
\hline \multirow{2}{*}{$\mathcal{U}^{N}$} & - & $\stackrel{m}{n}$ & $\stackrel{m}{n}$ & $\stackrel{m}{N}$ & $\stackrel{m}{n}$ & $\stackrel{m}{n}$ & $\stackrel{m}{N}$ & 0 & $\stackrel{m}{n}$ & $\stackrel{m}{\sim}$ & $\stackrel{m}{n}$ & 0 \\
\hline & 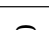 & ? & ? & 0 & 0 & 0 & O & 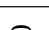 & 0 & 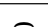 & 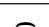 & 0 \\
\hline \multirow{3}{*}{ 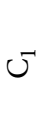 } & & & & & & $\infty$ & & & & & & \\
\hline & $=$ & $=$ & $=$ & $=$ & 4 & $=$ & $\stackrel{\infty}{\sim}$ & $\stackrel{\infty}{\sim}$ & $=$ & 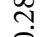 & $\stackrel{\infty}{\stackrel{\infty}{1}}$ & $\stackrel{\infty}{\infty}$ \\
\hline & 0 & 0 & 0 & 0 & 0 & 0 & 0 & 0 & 0 & 0 & 0 & 0 \\
\hline \multirow{3}{*}{$\mathfrak{n}^{N}$} & $\underset{\sigma}{\sigma}$ & 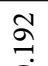 & 冓 & $\stackrel{2}{2}$ & 文 & ลู & $\stackrel{2}{\sigma}$ & $\stackrel{\infty}{\infty}$ & $\widetilde{\sigma}$ & ऽั & $\stackrel{\infty}{\infty}$ & $\widetilde{\Omega}$ \\
\hline & 0 & 0 & 0 & & 0 & & & & & & & \\
\hline & 0 & 0 & 0 & 0 & 0 & 0 & 0 & 0 & 0 & 0 & 0 & 0 \\
\hline \multirow{3}{*}{$\infty^{-1}$} & $\begin{array}{l}+\infty \\
-1\end{array}$ & $\stackrel{+}{\infty}$ & $\underset{-\infty}{\stackrel{\infty}{-1}}$ & $\underset{-\infty}{+\infty}$ & हे & $\stackrel{+}{\infty}$ & চ্ & $\underset{\sim}{\infty}$ & $\underset{\sim}{+}$ & 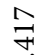 & 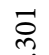 & $\underset{-\infty}{\not}$ \\
\hline & & 0 & 0 & 0 & & 0 & 0 & 0 & & & & \\
\hline & 0 & 0 & 0 & 0 & 0 & 0 & 0 & 0 & 0 & 0 & 0 & 0 \\
\hline $\mathbb{L}^{N}$ & 官 & $\begin{array}{l}+\infty \\
\stackrel{\infty}{0}\end{array}$ & $\begin{array}{l}+\infty \\
\stackrel{\infty}{0}\end{array}$ & $\stackrel{+}{\infty}$ & $\overrightarrow{0}$ & $\overrightarrow{\text { ș }}$ & $\stackrel{+}{\infty}$ & $\stackrel{+}{\infty}$ & \begin{tabular}{l}
$\vec{\infty}$ \\
\hdashline
\end{tabular} & 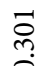 & 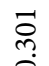 & $\stackrel{+}{\infty}$ \\
\hline \multirow{3}{*}{$\overline{4}$} & 0 & 0 & 0 & 0 & 0 & 0 & 0 & 0 & 0 & 0 & 0 & 0 \\
\hline & $\begin{array}{l}12 \\
0 \\
0\end{array}$ & $\begin{array}{l}\stackrel{\infty}{0} \\
\stackrel{1}{0} \\
0\end{array}$ & $\begin{array}{l}10 \\
0 \\
0 \\
0\end{array}$ & $\begin{array}{l}\text { ָ̃ } \\
\stackrel{1}{0}\end{array}$ & $\begin{array}{l}n \\
0 \\
0 \\
0\end{array}$ & 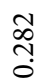 & 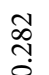 & 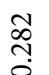 & 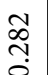 & $\begin{array}{l}\text { ָू } \\
\stackrel{1}{N}\end{array}$ & $\begin{array}{l}12 \\
0 \\
0\end{array}$ & $\begin{array}{l}120 \\
0 \\
0\end{array}$ \\
\hline & 0 & 0 & 0 & 0 & 0 & 0 & 0 & 0 & 0 & 0 & 0 & 0 \\
\hline $\begin{array}{l}\stackrel{0}{0} \\
\stackrel{0}{\Xi} \\
0 \\
0\end{array}$ & 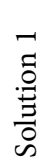 & 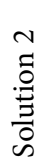 & 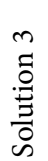 & $\begin{array}{l}+ \\
\stackrel{0}{0} \\
\stackrel{\Xi}{\Xi} \\
\stackrel{0}{0}\end{array}$ & 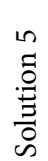 & 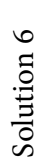 & $\begin{array}{l}\stackrel{\Lambda}{0} \\
\stackrel{0}{\Xi} \\
\stackrel{3}{0}\end{array}$ & 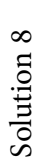 & $\begin{array}{l}a \\
\Xi \\
.0 \\
\stackrel{\Xi}{\Xi} \\
0 \\
\infty\end{array}$ & 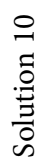 & 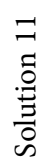 & 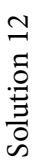 \\
\hline
\end{tabular}


Table 9. The weighted and the normalized weighted grey sums of positive and negatives distances from the average

\begin{tabular}{|l|c|c|c|c|c|c|c|c|}
\hline \multirow{2}{*}{ Solutions } & \multicolumn{3}{|c|}{$\otimes Q_{i}^{+}$} & \multicolumn{2}{|c|}{$\otimes Q_{i}^{-}$} & \multicolumn{2}{|c|}{$\otimes S_{i}^{+}$} & \multicolumn{2}{c|}{$\otimes S_{i}^{-}$} \\
\cline { 2 - 9 } & $Q_{i}^{+}$ & $\overline{Q_{i}^{+}}$ & $\underline{Q_{i}^{-}}$ & $\overline{Q_{i}^{-}}$ & $\underline{S_{i}^{+}}$ & $\overline{S_{i}^{+}}$ & $\underline{S_{i}^{-}}$ & $\overline{S_{i}^{-}}$ \\
\hline Solution 1 & 0.000 & 0.427 & 0.000 & 0.488 & 0.000 & 0.625 & 0.286 & 1.000 \\
\hline Solution 2 & 0.000 & 0.459 & 0.000 & 0.442 & 0.000 & 0.672 & 0.353 & 1.000 \\
\hline Solution 3 & 0.000 & 0.470 & 0.000 & 0.457 & 0.000 & 0.687 & 0.331 & 1.000 \\
\hline Solution 4 & 0.000 & 0.433 & 0.000 & 0.452 & 0.000 & 0.633 & 0.339 & 1.000 \\
\hline Solution 5 & 0.000 & 0.393 & 0.000 & 0.505 & 0.000 & 0.576 & 0.261 & 1.000 \\
\hline Solution 6 & 0.000 & 0.390 & 0.000 & 0.495 & 0.000 & 0.571 & 0.276 & 1.000 \\
\hline Solution 7 & 0.000 & 0.396 & 0.000 & 0.489 & 0.000 & 0.579 & 0.285 & 1.000 \\
\hline Solution 8 & 0.024 & 0.539 & 0.000 & 0.419 & 0.035 & 0.789 & 0.387 & 1.000 \\
\hline Solution 9 & 0.000 & 0.399 & 0.021 & 0.532 & 0.000 & 0.584 & 0.221 & 0.970 \\
\hline Solution 10 & 0.000 & 0.438 & 0.000 & 0.459 & 0.000 & 0.640 & 0.328 & 1.000 \\
\hline Solution 11 & 0.000 & 0.413 & 0.000 & 0.514 & 0.000 & 0.604 & 0.248 & 1.000 \\
\hline Solution 12 & 0.031 & 0.683 & 0.000 & 0.279 & 0.045 & 1.000 & 0.591 & 1.000 \\
\hline
\end{tabular}

Table 10. Estimated scores $\left(S_{i}\right)$

\begin{tabular}{|l|c|c|c|c|c|}
\hline \multicolumn{1}{|c|}{ Solutions } & $S_{i}$ & Rank & Solutions & $S_{i}$ & Rank \\
\hline Solution 1 & 0.478 & 7 & Solution 7 & 0.466 & 8 \\
\hline Solution 2 & 0.506 & 3 & Solution 8 & 0.553 & 2 \\
\hline Solution 3 & 0.505 & 4 & Solution 9 & 0.444 & 12 \\
\hline Solution 4 & 0.493 & 5 & Solution 10 & 0.492 & 6 \\
\hline Solution 5 & 0.459 & 11 & Solution 11 & 0.463 & 9 \\
\hline Solution 6 & 0.462 & 10 & Solution 12 & 0.659 & 1 \\
\hline
\end{tabular}

Based on the criteria weights obtained by the SWARA-Gray method, the ranking results of the solutions can be derived by these four methods. The final rankings of the solutions are presented in the form of Table 11. As can be seen, the results of the decision-making methods used in Gray environment are rarely changed. Therefore, the results of the applied model have acceptable stability.

In order to evaluate the performance of the EDAS-Gray method and measure the similarity of the results obtained from this method with the results of other selected methods, the Spearman rank correlation coefficient (Eq. (28)) is used, which is also applied by Barak and Heidary Dahooie (2018). 


$$
r_{s}=1-\frac{6 \sum_{i} d_{i}^{2}}{n^{3}-n},
$$

where $d_{i}$ indicates the difference between the rank of $i^{\text {th }}$ alternative in the EDAS-Gray method and the other methods and $n$ denotes the number of available pair values. The values of the Spearman rank correlation coefficient are given in Table 12.

Table 11. The ranking results derived from the selected MCDM methods

\begin{tabular}{|l|c|c|c|c|c|}
\hline \multicolumn{1}{|c|}{ Solutions } & SAW-G & COPRAS-G & TOPSIS_G & ARAS-G & EDAS-G \\
\hline Solution 1 & 6 & 7 & 12 & 9 & 7 \\
\hline Solution 2 & 4 & 4 & 9 & 2 & 3 \\
\hline Solution 3 & 3 & 3 & 4 & 10 & 4 \\
\hline Solution 4 & 5 & 6 & 11 & 1 & 5 \\
\hline Solution 5 & 9 & 9 & 6 & 12 & 11 \\
\hline Solution 6 & 10 & 11 & 8 & 7 & 10 \\
\hline Solution 7 & 7 & 10 & 10 & 5 & 8 \\
\hline Solution 8 & 2 & 2 & 2 & 4 & 2 \\
\hline Solution 9 & 12 & 12 & 5 & 6 & 12 \\
\hline Solution 10 & 8 & 5 & 7 & 8 & 6 \\
\hline Solution 11 & 11 & 8 & 3 & 11 & 9 \\
\hline Solution 12 & 1 & 1 & 1 & 3 & 1 \\
\hline
\end{tabular}

Table 12. Spearman rank correlation coefficient between the EDAS-G and selected methods

\begin{tabular}{|c|c|c|c|c|}
\hline Methods & SAW-G & COPRAS-G & TOPSIS_G & ARAS-G \\
\hline CC & 0.944056 & 0.951049 & 0.244755 & 0.552447552 \\
\hline
\end{tabular}

As can be seen, the EDAS-Gray method is highly correlated with COPRAS-Gray and SAW-Gray methods and less correlated with other two methods. This could be due to the use of the ideal solution with a different definition in the steps of these two methods.

\section{Conclusions and suggestions}

The supply chain encompasses all parties directly or indirectly involved in meeting customer needs. Improving supply chain performance has become increasingly important as competition has increased and supply chains have expanded in the present age. Hence, various paradigms such as lean, agile, resilience, and green are introduced to improve supply chain performance. Various combinations of different paradigms have also been used by researchers to improve supply chain performance. By examining the process of forming these paradigms, it can be asserted that the lean paradigm has always been one of the key components of modern approaches. The main purpose of the lean paradigm is to reduce costs and eliminate 
non-value-adding activities. Value engineering is a systematic process for achieving essential performance at the lowest cost. The executive experiences of the authors of this article show that in areas such as supply chain management, there are many opportunities for improvement that value engineering can facilitate their realization. However, value engineering has its limitations and drawbacks. The most important limitations of value engineering approach include overemphasizing the cost criterion and failure to meet other criteria, utilizing team members' votes to rank solutions, the lack of a framework to deal with the problem of inaccessibility of complete information (insufficient data for decision making), qualitative data collected, and uncertainty in the evaluations made by team members.

To address these problems, this paper attempted to identify and prioritize the cost reduction solutions in the supply chain by combining value engineering and Gray MCDM methods (SWARA and EDAS). Final cost reduction solutions were identified after numerous sessions with value engineering team. These solutions were then evaluated using criteria that were extracted from the research literature and adjusted and finalized by value engineering team members. The final criteria and sub-criteria were weighted using the Gray-SWARA method. Finally, the cost reduction solutions were prioritized using the EDAS-Gray method.

According to the calculated weights, the cost was the most important criterion. Prioritization results with the EDAS-Gray method showed that the solution 12 (Reduce order time to purchase and delivery by modifying the purchase procedure), solution 8 (Apply Design Data Freeze to the design process to estimate project financial and time costs), and solution 2 (Design after completing the input documents) were chosen as the best, respectively. The lower relative cost of the twelve solution and the better performance of this alternative in terms of flexibility and consistency with social perceptions and beliefs may be the reason for this preference.

According to the results of this research, the planning in the following sections should be carried out in the supply chain of combined cycle power plant: (1) Purchasing procedures need to be modified and the time delay between ordering and purchasing need to be reduced to increase the supply chain efficiency, (2) Design data freeze need to be applied to the design process to provide the necessary context for a more accurate estimation of financial costs, time, and better management of supply chain costs, which is the primary goal, and (3) The process steps must be redesigned so that the design can be completed once the entry documents have been completed. Besides, the unnecessary costs, increased procedures, and wasted time can be reduced by reducing equipment testing's bureaucracy through reducing the number of people required to perform the tests, reducing testing procedures, and not testing cables made by similar factory that have a test sheet. Also, by providing engineering documentation using ELECDES software, the cost and time can be reduced while maintaining the flexibility.

This research is the first attempt to use value engineering at the supply chain management level. Future research can utilize the value engineering approach in other supply chains in a variety of areas (especially responsive supply chains in industries such as the automotive industry). On the other hand, the level of expertise of each VE team member varies in different areas. Therefore, it is recommended future researches to use hesitant fuzzy sets (HFs) and proper group MCDM methods. The lack of a comprehensive list of criteria to prioritize 
solutions (approved by previous research) has been another challenge. It also seems logical that a systematic literature review (SLR) should be done to identify the list of criteria. Finally, it should be noted that some criteria can affect each other. Investigating the relationship between criteria and using methods such as DANP (a combination of DEMATEL and ANP) or FCM and its combination with metaheuristic methods (LFCM) can be pursued in future research.

\section{Disclosure statement}

The authors declare that there is no conflict of interest regarding the publication of this paper.

\section{References}

Aghdaie, M. H., Hashemkhani Zolfani, S., \& Zavadskas, E. K. (2014). Sales branches performance evaluation: a multiple attribute decision making approach. In 8th International Scientific Conference "Business and Management" 2014 (pp. 1-7). VGTU Press. https://doi.org/10.3846/bm.2014.001

Al-Aomar, R., \& Weriakat, D. (2012). A framework for a green and lean supply chain: A construction project application. In International Conference on Industrial Engineering and Operations Management Istanbul (pp. 289-299). http://iieom.org/ieom2012/pdfs/77.pdf

Amiri, M., Hashemi-Tabatabaei, M., Ghahremanloo, M., Keshavarz-Ghorabaee, M., Zavadskas, E. K., \& Banaitis, A. (2020). A new fuzzy BWM approach for evaluating and selecting a sustainable supplier in supply chain management. International Journal of Sustainable Development and World Ecology, 1-18. https://doi.org/10.1080/13504509.2020.1793424

Annappa, C. M., \& Panditrao, K. S. (2012). Application of value engineering for cost reduction-a case study of universal testing machine. International Journal of Advances in Engineering \& Technology, 4(1), 618-629. http://citeseerx.ist.psu.edu/viewdoc/download?doi=10.1.1.667.8337\&rep=rep1 \&type $=$ pdf

Assaf, S., Jannadi, O. A., \& Al-Tamimi, A. (2000). Computerized system for application of value engineering methodology. Journal of Computing in Civil Engineering, 14(3), 206-214. https://doi.org/10.1061/(ASCE)0887-3801(2000)14:3(206)

Azadeh, A., Haghnevis, M., \& Khodadadegan, Y. (2009). An improved model for production systems with mixed queuing priorities: an integrated simulation, AHP and Value Engineering approach. International Journal of Industrial and Systems Engineering, 4(5), 536-553. https://doi.org/10.1504/IJISE.2009.024157

Azevedo, S. G., Carvalho, H., \& Cruz-Machado, V. (2011). A proposal of LARG supply chain management practices and a performance measurement system. International Journal of e-Education, e-Business, e-Management and e-Learning, 1(1), 7-14. https://doi.org/10.7763/IJEEEE.2011.V1.2

Azevedo, S. G., Carvalho, H., \& Machado, V. C. (2010). The influence of larg supply chain management practices on manufacturing supply chain performance. Context, 3(25), 26-27.

Bai, C., \& Sarkis, J. (2018). Evaluating complex decision and predictive environments: the case of green supply chain flexibility. Technological and Economic Development of Economy, 24(4), 1630-1658. https://doi.org/10.3846/20294913.2018.1483977

Barak, S., \& Dahooei, J. H. (2018). A novel hybrid fuzzy DEA-Fuzzy MADM method for airlines safety evaluation. Journal of Air Transport Management, 73, 134-149.

https://doi.org/10.1016/j.jairtraman.2018.09.001 
Baušys, R., Juodagalvienė, B., Žiūrienė, R., Pankrašovaitė, I., Kamarauskas, J., Usovaitė, A., \& Gaižauskas, D. (2020). The residence plot selection model for family house in Vilnius by neutrosophic WASPAS method. International Journal of Strategic Property Management, 24(3), 182-196. https://doi.org/10.3846/ijspm.2020.12107

Beheshti, H. M. (2004). Gaining and sustaining competitive advantage with activity based cost management system. Industrial Management \& Data Systems, 104(5), 377-383. https://doi.org/10.1108/02635570410537462

Behncke, F. G., Maisenbacher, S., \& Maurer, M. (2014). Extended model for integrated value engineering. Procedia Computer Science, 28, 781-788. https://doi.org/10.1016/j.procs.2014.03.093

Bielinskas, V., Burinskiene, M., \& Podviezko, A. (2018). Choice of abandoned territories conversion scenario according to MCDA methods. Journal of Civil Engineering and Management, 24(1), 79-92. https://doi.org/10.3846/jcem.2018.303

Bock, S., \& Pütz, M. (2017). Implementing Value Engineering based on a multidimensional qualityoriented control calculus within a Target Costing and Target Pricing approach. International Journal of Production Economics, 183, 146-158. https://doi.org/10.1016/j.ijpe.2016.09.007

Bowen, P., Edwards, P., Cattell, K., \& Jay, I. (2010a). The awareness and practice of value management by South African consulting engineers: Preliminary research survey findings. International Journal of Project Management, 28(3), 285-295. https://doi.org/10.1016/j.ijproman.2009.07.001

Bowen, P., Jay, I., Cattell, K., \& Edwards, P. (2010b). Value management awareness and practice by South African architects: an empirical study. Construction Innovation, 10(2), 203-222. https://doi.org/10.1108/14714171011037192

Browning, T. R. (2000). Value-based product development: refocusing lean. In Proceedings of the 2000 IEEE Engineering Management Society. EMS-2000 (Cat. No. 00CH37139) (pp. 168-172). IEEE. https://doi.org/10.1109/ems.2000.872495

Buckley, P. J. (2009). The impact of the global factory on economic development. Journal of World Business, 44(2), 131-143. https://doi.org/10.1016/j.jwb.2008.05.003

Cabral, I., Grilo, A., \& Cruz-Machado, V. (2012). A decision-making model for lean, agile, resilient and green supply chain management. International Journal of Production Research, 50(17), 4830-4845. https://doi.org/10.1080/00207543.2012.657970

Carter, C. R., \& Rogers, D. S. (2008). A framework of sustainable supply chain management: moving toward new theory. International Journal of Physical Distribution \& Logistics Management, 38(5), 360-387 https://doi.org/10.1108/09600030810882816

Carvalho, H., \& Azevedo, S. (2014). Trade-offs among lean, agile, resilient and green paradigms in supply chain management: a case study approach. In Proceedings of the seventh international conference on management science and engineering management (pp. 953-968). Springer, Berlin, Heidelberg. https://doi.org/10.1007/978-3-642-40081-0_81

Carvalho, H., \& Cruz-Machado, V. (2011). Integrating lean, agile, resilience and green paradigms in supply chain management (LARG_SCM). In Supply Chain Management. InTech. https://doi.org/10.5772/14592

Carvalho, H., Azevedo, S. G., \& Cruz-Machado, V. (2010). Supply chain performance management: Lean and green paradigms. International Journal of Business Performance and Supply Chain Modelling, 2(3-4), 304-333. https://doi.org/10.1504/IJBPSCM.2010.036204

Carvalho, H., Duarte, S., \& Cruz Machado, V. (2011). Lean, agile, resilient and green: divergencies and synergies. International Journal of Lean Six Sigma, 2(2), 151-179. https://doi.org/10.1108/20401461111135037

Chatterjee, K., Pamucar, D., \& Zavadskas, E. K. (2018). Evaluating the performance of suppliers based on using the R'AMATEL-MAIRCA method for green supply chain implementation in electronics industry. Journal of Cleaner Production, 184, 101-129. https://doi.org/10.1016/j.jclepro.2018.02.186 
Chen, W. T., Chang, P. Y., \& Huang, Y. H. (2010). Assessing the overall performance of value engineering workshops for construction projects. International Journal of Project Management, 28(5), 514-527. https://doi.org/10.1016/j.ijproman.2009.08.005

Chopra, S., \& Meindl, P. (2013). Supply chain management: Strategy, planning, and operation-5/E. Pearson India.

Corbett, C. J., \& Klassen, R. D. (2006). Extending the horizons: Environmental excellence as key to improving operations. Manufacturing \& Service Operations Management, 8(1), 5-22. https://doi.org/10.1287/msom.1060.0095

Davis, S. M. (1997). Bringing innovation to life. Journal of Consumer Marketing, 14(5), 338-361. https://doi.org/10.1108/07363769710179383

Dehnavi, A., Aghdam, I. N., Pradhan, B., \& Varzandeh, M. H. M. (2015). A new hybrid model using step-wise weight assessment ratio analysis (SWARA) technique and adaptive neuro-fuzzy inference system (ANFIS) for regional landslide hazard assessment in Iran. Catena, 135, 122-148. https://doi.org/10.1016/j.catena.2015.07.020

Dell'Isola, A. J. (1982). Value engineering in the construction industry. Van Nostrand Reinhold.

Deng, J. L. (1982). Control problems of grey systems. Systems \& Control Letters, 1(5), 288-294. https://doi.org/10.1016/S0167-6911(82)80025-X

Dorvil, M., \& Benjamin, C. O. (2002). Value engineering in supply chain management. In Proceedings of the 5th Biannual World Automation Congress, 14, 169-174. IEEE. https://doi.org/10.1109/WAC.2002.1049438

Elgazzar, S. H., Tipi, N. S., Hubbard, N. J., \& Leach, D. Z. (2012). Linking supply chain processes' performance to a company's financial strategic objectives. European Journal of Operational Research, 223(1), 276-289. https://doi.org/10.1016/j.ejor.2012.05.043

Ellis, R. C., Wood, G. D., \& Keel, D. A. (2005). Value management practices of leading UK cost consultants. Construction Management and Economics, 23(5), 483-493. https://doi.org/10.1080/01446190500040711

El-Nashar, W. Y. (2017). Effect of drains coverings on environment by using value engineering. Alexandria Engineering Journal, 56(3), 327-332. https://doi.org/10.1016/j.aej.2017.05.013

Fan, Q., Xu, X., \& Gong, Z. (2007). Research on lean, agile and leagile supply chain. In 2007 International Conference on Wireless Communications, Networking and Mobile Computing, (pp. 4902-4905). IEEE. https://doi.org/10.1109/WICOM.2007.1201

Fan, S., Shen, Q., \& Kelly, J. (2008). Using group decision support system to support value management workshops. Journal of Computing in Civil Engineering, 22(2), 100-113.

https://doi.org/10.1061/(ASCE)0887-3801(2008)22:2(100)

Fong, P. S. W. (2004). A critical appraisal of recent advances and future directions in value management. European Journal of Engineering Education, 29(3), 377-388.

https://doi.org/10.1080/03043790410001663292

Fong, P. S. W., Hills, M. J., \& Hayles, C. S. (2007). Dynamic knowledge creation through value management teams. Journal of Management in Engineering, 23(1), 40-49. https://doi.org/10.1061/(ASCE)0742-597X(2007)23:1(40)

Gandhinathan, R., Raviswaran, N., \& Suthakar, M. (2004). QFD-and VE-enabled target costing: a fuzzy approach. International Journal of Quality \& Reliability Management, 21(9), 1003-1011. https://doi.org/10.1108/02656710410561817

Govindan, K., Azevedo, S. G., Carvalho, H., \& Cruz-Machado, V. (2015). Lean, green and resilient practices influence on supply chain performance: Interpretive structural modeling approach. International Journal of Environmental Science and Technology, 12(1), 15-34. https://doi.org/10.1007/s13762-013-0409-7 
Green, S. D. (1994). Beyond value engineering: SMART value management for building projects. International Journal of Project Management, 12(1), 49-56. https://doi.org/10.1016/0263-7863(94)90009-4

Gunasekaran, A., Laib, K., \& Cheng, T. C. E. (2008). Responsive supply chain: A competitive strategy in a networked economy. Omega, 36(4), 549-564. https://doi.org/10.1016/j.omega.2006.12.002

Gunasekaran, A., Patel, C., \& Tirtiroglu, E. (2001). Performance measures and metrics in a supply chain environment. International Journal of Operations \& Production Management, 21(1/2), 71-87. https://doi.org/10.1108/01443570110358468

Hashemkhani Zolfani, S., \& Saparauskas, J. (2013). New application of SWARA method in prioritizing sustainability assessment indicators of energy system. Inzinerine Ekonomika-Engineering Economics, 24(5), 408-414. https://doi.org/10.5755/j01.ee.24.5.4526

Hashemkhani Zolfani, S., Aghdaie, M. H., Derakhti, A., Zavadskas, E. K., \& Varzandeh, M. H. M. (2013). Decision making on business issues with foresight perspective; an application of new hybrid MCDM model in shopping mall locating. Expert Systems with Applications, 40(17), 7111-7121. https://doi.org/10.1016/j.eswa.2013.06.040

Hashemkhani Zolfani, S., Yazdani, M., \& Zavadskas, E. K. (2018). An extended stepwise weight assessment ratio analysis (SWARA) method for improving criteria prioritization process. Soft Computing, 22(22), 7399-7405. https://doi.org/10.1007/s00500-018-3092-2

Heidary Dahooie, J., Vanaki, A. S., Daneshmoghadam, S., \& Zavadskas, E. K. (2020). A framework to overcome hesitancy of decision-makers in e-government web site evaluation. International Journal of Fuzzy Systems, 22, 583-603. https://doi.org/10.1007/s40815-019-00790-z

Heidary Dahooie, J., Zavadskas, E. K., Firoozfar, H. R., Vanaki, A. S., Mohammadi, N., \& Brauers, W. K. M. (2019). An improved fuzzy MULTIMOORA approach for multi-criteria decision making based on objective weighting method (CCSD) and its application to technological forecasting method selection. Engineering Applications of Artificial Intelligence, 79, 114-128.

https://doi.org/10.1016/j.engappai.2018.12.008

Ibusuki, U., \& Kaminski, P. C. (2007). Product development process with focus on value engineering and target-costing: A case study in an automotive company. International Journal of Production Economics, 105(2), 459-474. https://doi.org/10.1016/j.ijpe.2005.08.009

Jahanshahloo, G. R., Lotfi, F. H., \& Izadikhah, M. (2006). An algorithmic method to extend TOPSIS for decision-making problems with interval data. Applied Mathematics and Computation, 175(2), 1375-1384. https://doi.org/10.1016/j.amc.2005.08.048

Jasti, N. V. K., \& Kodali, R. (2015). A critical review of lean supply chain management frameworks: Proposed framework. Production Planning \& Control, 26(13), 1051-1068. https://doi.org/10.1080/09537287.2015.1004563

Kaliszewski, I., \& Podkopaev, D. (2016). Simple additive weighting - A metamodel for multiple criteria decision analysis methods. Expert Systems with Applications, 54, 155-161.

https://doi.org/10.1016/j.eswa.2016.01.042

Karabasevic, D., Zavadskas, E. K., Stanujkic, D., Popovic, G., \& Brzakovic, M. (2018). An approach to personnel selection in the IT industry based on the EDAS method. Transformations in Business and Economics, 17(2), 55-65.

Kelly, J. (2007). Making client values explicit in value management workshops. Construction Management and Economics, 25(4), 435-442. https://doi.org/10.1080/01446190601071839

Kersuliene, V., Zavadskas, E. K., \& Turskis, Z. (2010). Selection of rational dispute resolution method by applying new step-wise weight assessment ratio analysis (SWARA). Journal of Business Economics and Management, 11(2), 243-258. https://doi.org/10.3846/jbem.2010.12

Keshavarz Ghorabaee, M., Amiri, M., Zavadskas, E. K., \& Antucheviciene, J. (2018). A new hybrid fuzzy MCDM approach for evaluation of construction equipment with sustainability considerations. Archives of Civil and Mechanical Engineering, 18(1), 32-49. https://doi.org/10.1016/j.acme.2017.04.011 
Keshavarz Ghorabaee, M., Zavadskas, E. K., Amiri, M., \& Turskis, Z. (2016). Extended EDAS method for fuzzy multi-criteria decision-making: an application to supplier selection. International Journal of Computers Communications \& Control, 11(3), 358-371. https://doi.org/10.15837/ijccc.2016.3.2557

Keshavarz Ghorabaee, M., Zavadskas, E. K., Olfat, L., \& Turskis, Z. (2015). Multi-criteria inventory classification using a new method of evaluation based on distance from average solution (EDAS). Informatica, 26(3), 435-451. https://doi.org/10.15388/Informatica.2015.57

Kildienè, S., Kaklauskas, A., \& Zavadskas, E. K. (2011). COPRAS based comparative analysis of the European country management capabilities within the construction sector in the time of crisis. Journal of Business Economics and Management, 12(2), 417-434.

https://doi.org/10.3846/16111699.2011.575190

Kumar, A., Moktadir, A., Liman, Z. R., Gunasekaran, A., Hegemann, K., \& Rehman Khan, S. A. (2020a). Evaluating sustainable drivers for social responsibility in the context of ready-made garments supply chain. Journal of Cleaner Production, 248, 119231. https://doi.org/10.1016/j.jclepro.2019.119231

Kumar, A., Moktadir, M. A., Khan, S. A. R., Garza-Reyes, J. A., Tyagi, M., \& Kazançoğlu, Y. (2020b). Behavioral factors on the adoption of sustainable supply chain practices. Resources, Conservation and Recycling, 158, 104818. https://doi.org/10.1016/j.resconrec.2020.104818

Kumar, A., Zavadskas, E. K., Mangla, S. K., Agrawal, V., Sharma, K., \& Gupta, D. (2019). When risks need attention: adoption of green supply chain initiatives in the pharmaceutical industry. International Journal of Production Research, 57(11), 3554-3576.

https://doi.org/10.1080/00207543.2018.1543969

Li, Z., Wei, G., Wang, R., Wu, J., Wei, C., \& Wei, Y. (2020). EDAS method for multiple attribute group decision making under q-rung orthopair fuzzy environment. Technological and Economic Development of Economy, 26(1), 86-102. https://doi.org/10.3846/tede.2019.11333

Lin, G., Shen, G. Q., Sun, M., \& Kelly, J. (2011). Identification of key performance indicators for measuring the performance of value management studies in construction. Journal of Construction Engineering and Management, 137(9), 698-706. https://doi.org/10.1061/(ASCE)CO.1943-7862.0000348

MacCrimmon, K. R. (1968). Decisionmaking among multiple-attribute alternatives: a survey and consolidated approach (No. RM-4823-ARPA). Rand Corp. Santa Monica CA.

Mahdi, I. M., Heiza, K. M., \& Elenen, N. E. (2015). State of the art review on application of value engineering on construction projects: High rise building. International Journal of Innovative Research in Science, Engineering and Technology, 1.

Maleki, M., \& Machado, V. C. (2013). Generic integration of lean, agile, resilient, and green practices in automotive supply chain. Revista de Management Comparat International/Review of International Comparative Management, 14(2), 237-248.

Manzouri, M., \& Rahman, M. N. A. (2013). Adaptation of theories of supply chain management to the lean supply chain management. International Journal of Logistics Systems and Management, 14(1), 38-54. https://doi.org/10.1504/IJLSM.2013.051019

Marzouk, M. M. (2011). ELECTRE III model for value engineering applications. Automation in Construction, 20(5), 596-600. https://doi.org/10.1016/j.autcon.2010.11.026

Mavi, R. K., Zarbakhshnia, N., \& Khazraei, A. (2018). Bus rapid transit (BRT): A simulation and multi criteria decision making (MCDM) approach. Transport Policy, 72, 187-197. https://doi.org/10.1016/j.tranpol.2018.03.010

Nascimento, D. L. M., Quelhas, O. L. G., Meiriño, M. J., Caiado, R. G. G., Barbosa, S. D. J., \& Ivson, P. (2018). Facility Management using digital Obeya Room by integrating BIM-Lean approaches - an empirical study. Journal of Civil Engineering and Management, 24(8), 581-591. https://doi.org/10.3846/jcem.2018.5609 
Nucciarelli, A., Li, F., Fernandes, K. J., Goumagias, N., Cabras, I., Devlin, S., Kudenko, D., \& Cowling, P. (2017). From value chains to technological platforms: The effects of crowdfunding in the digital game industry. Journal of Business Research, 78, 341-352.

https://doi.org/10.1016/j.jbusres.2016.12.030

Opricovic, S. (1998). Multicriteria optimization of civil engineering systems. Faculty of Civil Engineering, Belgrade, 2(1), 5-21.

Pan, W., Jian, L., \& Liu, T. (2019). Grey system theory trends from 1991 to 2018: a bibliometric analysis and visualization. Scientometrics, 121(3), 1407-1434. https://doi.org/10.1007/s11192-019-03256-Z

Rachwan, R., Abotaleb, I., \& Elgazouli, M. (2016). The influence of value engineering and sustainability considerations on the project value. Procedia Environmental Sciences, 34, 431-438. https://doi.org/10.1016/j.proenv.2016.04.038

Shen, G., \& Yu, A. T. (2012). Value management: Recent developments and way forward. Construction Innovation, 12(3), 264-271. https://doi.org/10.1108/14714171211244631

Stanujkic, D., Karabasevic, D., \& Zavadskas, E. K. (2015). A framework for the selection of a packaging design based on the SWARA method. Inzinerine Ekonomika-Engineering Economics, 26(2), 181-187. https://doi.org/10.5755/j01.ee.26.2.8820

Stanujkic, D., Zavadskas, E. K., Keshavarz Ghorabaee, M., \& Turskis, Z. (2017). An extension of the EDAS method based on the use of interval grey numbers. Studies in Informatics and Control, 26(1), 5-12. https://doi.org/10.24846/v26ily201701

Stević, Ž., Vasiljević, M., Puška, A., Tanackov, I., Junevičius, R., \& Vesković, S. (2019). Evaluation of suppliers under uncertainty: a multiphase approach based on fuzzy AHP and fuzzy EDAS. Transport, 34(1), 52-66. https://doi.org/10.3846/transport.2019.7275

$\mathrm{Su}, \mathrm{T}$. Y., \& Lei, X. H. (2008). Research on supply chain cost reduction based on process and time analysis. In 2008 IEEE International Conference on Industrial Engineering and Engineering Management (pp. 1625-1629). https://doi.org/10.1109/IEEM.2008.4738147

Surlan, N., Cekic, Z., \& Torbica, Z. (2016). Use of value management workshops and critical success factors in introducing local experience on the international construction projects. Journal of Civil Engineering and Management, 22(8), 1021-1031. https://doi.org/10.3846/13923730.2014.945950

Tohidi, H. (2011). Review the benefits of using value engineering in information technology project management. Procedia Computer Science, 3, 917-924. https://doi.org/10.1016/j.procs.2010.12.150

Turskis, Z., \& Zavadskas, E. K. (2010). A novel method for multiple criteria analysis: grey additive ratio assessment (ARAS-G) method. Informatica, 21(4), 597-610. https://doi.org/10.15388/Informatica.2010.307

Valipour, A., Yahaya, N., Noor, N. M., Valipour, I., \& Tamošaitienè, J. (2019). A SWARA-COPRAS approach to the allocation of risk in water and sewerage public-private partnership projects in Malaysia. International Journal of Strategic Property Management, 23(4), 269-283.

https://doi.org/10.3846/ijspm.2019.8066

Wao, J., \& MQSI, S. (2015). A review of the value engineering methodology: Limitations and solutions for sustainable construction. In 55th SAVE International Annual Conference: SAVE Value Summit, (pp. 7-9).

Wu, H. H. (2006). Applying grey model to prioritise technical measures in quality function deployment. The International Journal of Advanced Manufacturing Technology, 29(11-12), 1278-1283. https://doi.org/10.1007/s00170-005-0016-y

Yazdani, M., Wen, Z., Liao, H., Banaitis, A., \& Turskis, Z. (2019). A grey combined compromise solution (CoCoSo-G) method for supplier selection in construction management. Journal of Civil Engineering and Management, 25(8), 858-874. https://doi.org/10.3846/jcem.2019.11309 
Yoon, K. P., \& Hwang, C. L. (1995). Multiple attribute decision making: an introduction. Sage Publications. https://doi.org/10.4135/9781412985161

Zarandi, M. H. F., Razaee, Z. S., \& Karbasian, M. (2011). A fuzzy case based reasoning approach to value engineering. Expert Systems with Applications, 38(8), 9334-9339.

https://doi.org/10.1016/j.eswa.2011.01.124

Zavadskas, E. K., Stević, Ž., Turskis, Z., \& Tomasević, M. (2019). A novel extended EDAS in Minkowski space (EDAS-M) method for evaluating autonomous vehicles. Studies in Informatics and Control, 28(3), 255-264. https://doi.org/10.24846/v28i3y201902

Zavadskas, E. K., Vilutiene, T., Turskis, Z., \& Tamosaitiene, J. (2010). Contractor selection for construction works by applying SAW-G and TOPSIS grey techniques. Journal of Business Economics and Management, 11(1), 34-55. https://doi.org/10.3846/jbem.2010.03

Zengin, Y., \& Ada, E. (2010). Cost management through product design: target costing approach. International Journal of Production Research, 48(19), 5593-5611. https://doi.org/10.1080/00207540903130876

Zhang, S., Wei, G., Gao, H., Wei, C., \& Wei, Y. (2019). EDAS method for multiple criteria group decision making with picture fuzzy information and its application to green suppliers selections. Technological and Economic Development of Economy, 25(6), 1123-1138. https://doi.org/10.3846/tede.2019.10714

Zhang, X., Mao, X., \& AbouRizk, S. M. (2009). Developing a knowledge management system for improved value engineering practices in the construction industry. Automation in Construction, 18(6), 777-789. https://doi.org/10.1016/j.autcon.2009.03.004 